OECD Statistics Working Papers 2016/04

Unemployment, temporary work and subjective wellbeing: Gendered effect of spousal labour market insecurity in the United Kingdom

\section{Hande Inanc}

https://dx.doi.org/10.1787/5jlz6qjsf36c-en 
Organisation de Coopération et de Développement Économiques

Organisation for Economic Co-operation and Development

STATISTICS DIRECTORATE

English - Or. English

UNEMPLOYMENT, TEMPORARY WORK AND SUBJECTIVE WELL-BEING: GENDERED EFFECT OF SPOUSAL LABOUR MARKET INSECURITY IN THE UNITED KINGDOM

\section{WORKING PAPER No.70}

Contact: Hande Inanc, Statistics Directorate, +(33-1) 452413 15; Hande.INANC@oecd.org

\section{JT03395056}

Complete document available on OLIS in its original format

This document and any map included herein are without prejudice to the status of or sovereignty over any territory, to the delimitation of international frontiers and boundaries and to the name of any territory, city or area. 
STD/DOC(2016)4

UNEMPLOYMENT, TEMPORARY WORK AND SUBJECTIVE WELL-BEING: GENDERED EFFECT OF SPOUSAL LABOUR MARKET INSECURITY IN THE UNITED KINGDOM

Hande INANC, OECD Statistics Directorate 


\section{OECD STATISTICS WORKING PAPER SERIES}

The OECD Statistics Working Paper Series - managed by the OECD Statistics Directorate - is designed to make available in a timely fashion and to a wider readership selected studies prepared by OECD staff or by outside consultants working on OECD projects. The papers included are of a technical, methodological or statistical policy nature and relate to statistical work relevant to the Organisation. The Working Papers are generally available only in their original language - English or French - with a summary in the other.

OECD Working Papers should not be reported as representing the official views of the OECD or of its member countries. The opinions expressed and arguments employed are those of the author.

Working Papers describe preliminary results or research in progress by the author and are published to stimulate discussion on a broad range of issues on which the OECD works. Comments on Working Papers are welcomed, and may be sent to the Statistics Directorate, OECD, 2 rue André-Pascal, 75775 Paris Cedex 16, France.

The release of this working paper has been authorised by Martine Durand, OECD Chief Statistician and Director of the OECD Statistics Directorate.

www.oecd.org/std/publicationsdocuments/workingpapers/ 


\begin{abstract}
This paper investigates the extent to which unemployment and temporary work - two forms of labour market insecurity - affect different aspects of subjective well-being (i.e. life satisfaction, psychological well-being and satisfaction with partnership) among legally married and cohabiting couples in the United Kingdom. Drawing on matched data for couples from the British Household Panel Study, the paper shows that both forms of labour market insecurity, when experienced by the male partner, lower significantly the psychological well-being and life satisfaction of the female partner; women's temporary work also slightly lowers men's psychological well-being. The impact of spousal labour market insecurity depends, however, on the employment status of the individual: after controlling for financial strain, psychological well-being and life-satisfaction of both partners in a couple are hampered the most when men are economically dependent on their female partners. In the case of partnership satisfaction, results differ from the other two subjective well-being outcomes: while unemployment of the female partner is associated with higher satisfaction for men, partnership satisfaction is particularly low when both partners experience either form of labour market insecurity. These effects are robust after controlling for fixed individual characteristics that can influence both employment status and well-being outcomes.
\end{abstract}

\title{
RÉSUMÉ
}

Ce document analyse dans quelle mesure le chômage et le travail temporaire - deux types d'insécurité du marché du travail - influent sur différentes dimensions du bien-être subjectif (satisfaction à l'égard de la vie, bien-être psychologique et satisfaction à l'égard de la vie de couple) des couples au Royaume-Uni, mariés ou non. En s'appuyant sur des données appariées issues de l'enquête British Household Panel Study réalisée auprès des ménages, ce document montre que ces deux exemples de l'insécurité du marché du travail, lorsqu'ils sont vécus, au sein du couple, par l'homme, ont un effet négatif sensible sur le bien-être psychologique et la satisfaction à l'égard de la vie de la femme ; le travail temporaire des femmes a également un effet légèrement négatif sur le bien-être psychologique des hommes. L'impact de l'insécurité du marché du travail sur le couple dépend toutefois de la situation au regard de l'emploi de chacun de ses membres : après prise en compte des difficultés financières, c'est la dépendance économique de l'homme par rapport à la femme qui pèse le plus fortement sur le bien-être psychologique et la satisfaction à l'égard de la vie des deux conjoints. S'agissant de la satisfaction à l'égard de la vie de couple, les résultats divergent par rapport aux deux autres dimensions du bien-être subjectif : si le chômage de la femme est associé à une plus grande satisfaction à l'égard de la vie chez les hommes, la satisfaction à l'égard de la vie de couple est particulièrement faible lorsque les deux conjoints sont touchés soit par le chômage soit par le travail temporaire. Ces effets persistent après prise en compte des caractéristiques individuelles fixes susceptibles d'influencer la situation au regard de l'emploi et le bien-être. 


\section{ACKNOWLEDGEMENTS}

The author would like to thank Marco Mira d'Ercole, Conal Smith and Carrie Exton (from the OECD Statistics Directorate) for their detailed comments and useful suggestions. Earlier drafts of this paper have benefited extensively from careful readings of Evrim Altintaş, Hans-Peter Blossfeld, Duncan Gallie, Jay Gershuny, Arne Kalleberg, Berkay Özcan and Alexa Tiemman. 
TABLE OF CONTENTS

UNEMPLOYMENT, TEMPORARY WORK AND SUBJECTIVE WELL-BEING: GENDERED EFFECT OF SPOUSAL LABOUR MARKET INSECURITY IN THE UNITED KINGDOM...................2

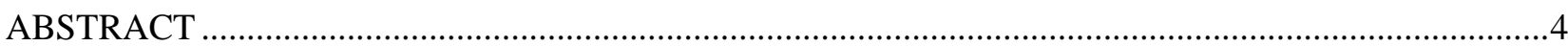

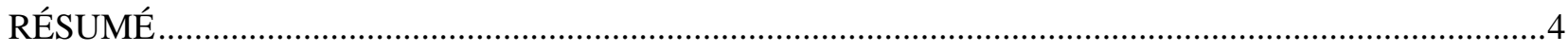

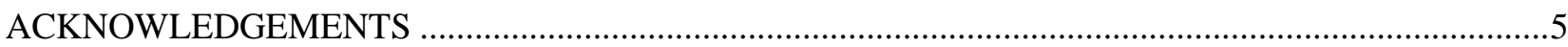

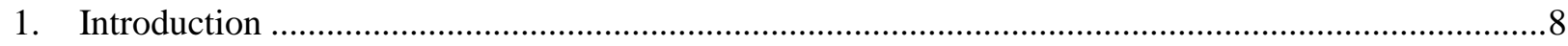

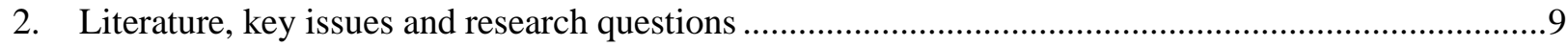

2a. What makes labour market insecurity harmful for subjective well-being? ...............................9

2b. Labour market insecurity and spousal well-being .................................................................

2c. Couples' joint labour market status and subjective well-being ..............................................10

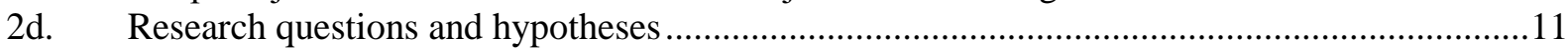

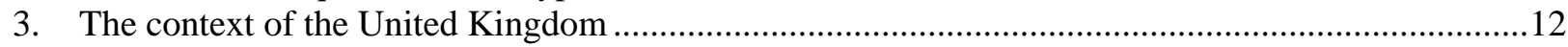

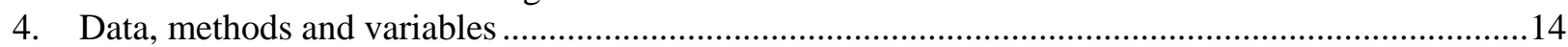

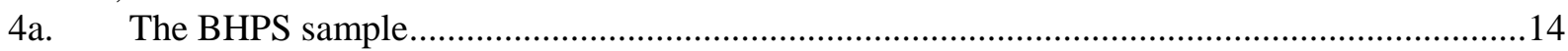

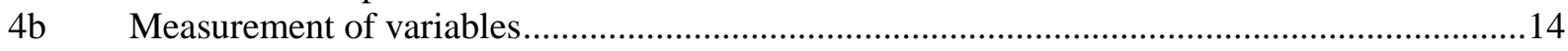

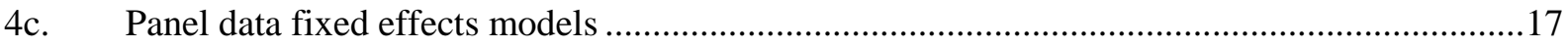

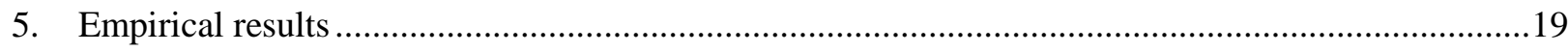

5a. Husbands' labour market insecurity and wives' subjective well-being ..................................19

5b. Wives' labour market insecurity and husbands' subjective well-being ....................................21

5c. Couple employment dynamics and subjective well-being ......................................................23

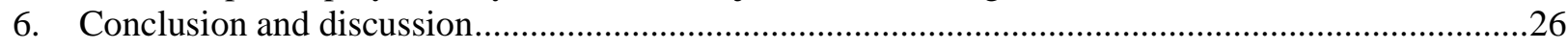

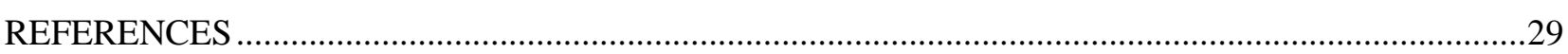

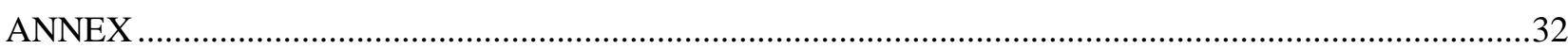

\section{Tables}

Table 1. Husbands' labour market insecurity and wives' subjective well-being, fixed-effect

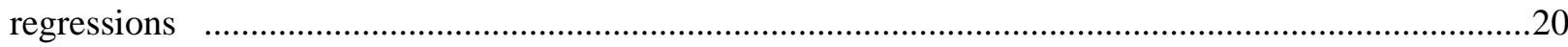

Table 2. Wives' labour market insecurity and husbands' subjective well-being, fixed-effect

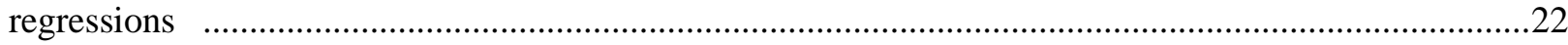

Table 3. Subjective well-being and labour market insecurity at the couple level ............................25

Table A1. Distribution of the BHPS sample by employment status, Waves 1-18 ..............................32

Table A2. Labour market insecurity among couples and subjective well-being outcomes, descriptive

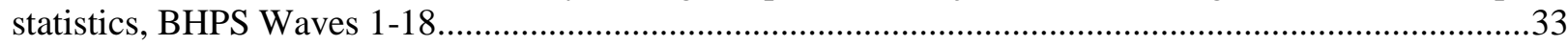

Table A3. Husbands' labour market insecurity and wives' subjective well-being, model comparisons.34

Table A4. Wives' labour market insecurity and husband's subjective well-being, model comparisons.35 


\section{Figures}

Figure 1. Employment protection legislation in the UK and the OECD average, 1985-2013 .............13

Figure 2. Percentage of temporary workers in the United Kingdom, 1983-2012 ............................13

Figure 3. Year-to-year transition rates from temporary to permanent contracts in the United Kingdom,

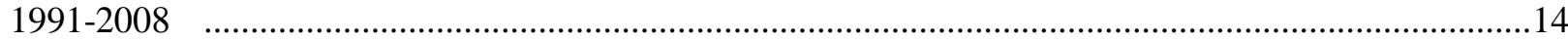

Figure 4. Distribution of psychological well-being scores across respondents ...............................15

Figure 5. Distribution of life satisfaction scores across respondents .............................................16

Figure 6. Distribution of partnership satisfaction scores across respondents ....................................16

Figure 7. Couples' joint labour market insecurity and subjective well-being ....................................24

\section{Boxes}

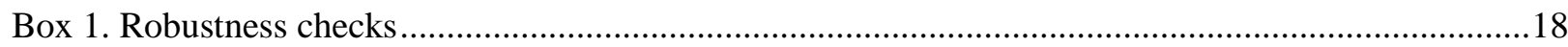




\section{Introduction}

1. Since the late 1970s, many industrial countries adopted a process of deregulation of labour markets to combat increasing pressures from the internationalization of markets, competition, spread of technological innovations and mass unemployment. These policies made it easier for employers to shift market risks to employees by means of non-standard employment types in order to meet the requirements of more global and volatile markets. One consequence of this process is that the proportion of the workforce protected with employment rights declined, leading to a rise in labour market insecurity. Unemployment remained as a major source of insecurity and uncertainty for both individuals and their spouses; but, non-standard types of employment, in particular temporary employment, have become another increasingly important source.

2. The negative impact of unemployment on individuals' and their spouses' subjective well-being is well-documented. However, much less is known on the consequences of temporary jobs for the well-being of spouses. Temporary employees (i.e. those with fixed-term contracts, in casual or seasonal work, and temporary agency workers) typically have lower subjective well-being compared to permanent employees (i.e. those with open-ended contracts). But much less in known about the extent to which temporary work affects the well-being of the spouses of temporary employees. Temporary workers experience a great deal of stress resulting from their peripheral position in the labour market, lower intrinsic job quality and the strain arising from fulfilling work-tasks whilst often looking for a permanent job. The partner of a temporarily-employed worker could experience a sense of insecurity, uncertainty, frustration, hence lower subjective well-being. This paper examines the impact of temporary jobs on the subjective well-being of spouses (both legally married and cohabiting ones) in the United Kingdom, and investigates whether this more recent but expanding form of insecurity has similar repercussions on spouses' well-being as unemployment does.

3. The ways in which labour market insecurity affects couples is likely to depend on the relationship between the employment status of spouses, and could also be associated with different outcomes for husbands and wives. For instance, couples where both spouses go through labour market insecurity could be negatively affected in particular. Alternatively, the insecurity associated with the male partner could be more damaging for his subjective well-being if the female partner is securely employed, threatening the gender roles within the household. This negative impact could be greater for men than for women. This paper examines the impact of labour market insecurity on couples, looking at main and interaction effects of the labour market status of each partner on the subjective well-being of their partner, and examines these alternative scenarios for husbands and wives.

4. Subjective well-being is a multidimensional concept covering multiple aspects of a person's subjective state (e.g. Diener et al. 1999; Kahneman, Diener and Schwarz 1999) and labour market insecurity can influence some dimensions of the subjective well-being more than others. The OECD Guidelines on Measuring Subjective Well-being considers three aspects: Life evaluation, which is a reflective assessment on a person's life or some specific aspects of it; affect, which refers to a person's feelings or emotional states, typically measured with reference to a particular point in time; and eudemonia, which refers to a sense of meaning and purpose in life, or good psychological functioning (OECD 2013, p: 10). The paper considers a measure of overall life evaluation (namely, life satisfaction), and one domain-specific evaluation: satisfaction with partnership. In addition, it considers a common measure of psychological functioning (combining elements of eudemonia and long-term affect), the 12item version of the General Health Questionnaire. It compares the impact of labour market insecurity on these three subjective well-being outcomes of wives and husbands.

5. This paper bridges the ground between two OECD workstreams. First, the OECD work on job quality focuses on those aspects of employment that are most important for workers' well-being (Cazes, 
Hijzen and Saint-Martin 2016). Building on the influential report by the Commission on the Measurement of Economic Performance and Social Progress (Stiglitz, Sen and Fitoussi, 2008), the OECD job quality framework is based on three policy-relevant complementary factors: i) "earnings quality", defined as the combination of average earnings and their distribution across the workforce, captures the contribution of jobs to workers' material living conditions,; ii) "labour market security" measures the risk for workers to lose their job and its consequences for themselves and their families; and iii) "the quality of working environment" considers job stressors (such as time pressure and physical risk factors) together with resources available to workers (such as autonomy, learning opportunities and support from colleagues) in order to capture the non-economic features of work. Second, the OECD's Better Life Initiative considers subjective well-being as one of the eleven key dimensions of people's well-being, defining as "good mental states, including all of the various evaluations, positive and negative, that people make for their lives and the affective reactions of people to their experiences" (OECD 2013, p.10).

6. The contributions of the paper are threefold: First, by using a broader definition of labour market insecurity and assessing the potential repercussions of temporary jobs on the subjective well-being of both partners in a couple, it investigates whether and to what extent temporary jobs are similar to unemployment in terms of their impact on spousal well-being. Second, by providing further analysis of couples' labour market status, it investigates the importance of the employment conditions of both partners in a couple and the gendered impact on the subjective well-being of both women and men. Third, since subjective wellbeing is itself a multidimensional phenomenon, the paper investigates the differences in the way various facets of people's subjective well-being are influenced by their partners' labour market insecurity.

7. The empirical analysis draws on data from 18 waves of the British Household Panel Study, a nationally representative survey of individuals conducted from 1991 to 2008, which has extensive information on yearly changes in employment status and well-being outcomes of individuals and their partners, as well as on a number of factors relevant to subjective well-being. Section 2 reviews the literature on labour market insecurity and subjective well-being and briefly discusses the specific research questions the paper addresses. Section 3 provides an overview of the British context and of the research questions addressed in the paper. Section 4 describes the data, methods and variables used in the empirical analysis. Section 5 presents the empirical results, while Section 6 concludes with a discussion of their implications for policies.

\section{Literature, key issues and research questions}

\section{2a. What makes labour market insecurity harmful for subjective well-being?}

8. Several researchers have consistently documented that unemployment is associated with lower levels of life satisfaction, psychological well-being, and happiness, across different countries and using different datasets (see, for example, Clark and Oswald, 1994; Clark, 2003; Green, 2011; Frey and Stutzer, 2002; Murphy and Athanasau, 1999; Nordenmark and Strandh, 1991). Moreover, this effect appears to be independent of pre-existing psychological health conditions (this relationship was identified as early as Banks and Jackson 1982). This detrimental effect of unemployment on people's subjective well-being has been attributed to various mechanisms: pecuniary aspects of job loss, such as financial problems arising from changes in family income (Jackson and Warr, 1984); having to borrow money (White, 1991); being in debt (Heady and Smith, 1989); and the non-pecuniary aspects of job loss, such as the loss of time structure, status and identity (Jahoda 1982) and opportunities for self-realization (Warr, 1987).

9. There is evidence that temporary work is also associated with stress and poor psychological wellbeing. Research has identified three major sources of stress for temporary workers which in turn can result in reduced subjective well-being: i) stress that arises from the peripheral position of temporary employees in the labour market and the consequent under-investment in them by their employers (Inanc, 2015; De 
Witte and Naswall, 2003); ii) job strain due to the poor quality of temporary jobs such as the low level of work autonomy and the lack of opportunities for organizational participation (Inanc et al., 2015; Hall, 2006, Arronsson et al., 2002, Parker et al., 2002); and iii) the employment strain that arises from a combination of the demands associated to the constant search for a better (permanent) job and the need to ensure a positive assessment of work performance by the current employer (Lewchuck et al., 2008). Empirical studies lend support to the adverse effect of these stressors on physical and psychological wellbeing for some temporary workers (see Artazcoz et al., 2005 for Spanish fixed-term and no-contract workers; Rodruiguez, 2002 for German fixed-term workers; also Virtanen et al., 2005 for a review).

\section{2b. Labour market insecurity and spousal well-being}

10. In addition to the adverse effect of labour market insecurity on individuals' own subjective wellbeing, there is also a growing literature on how this insecurity negatively influences the well-being of spouses. Much of this research has focused on the consequences of unemployment: it is well-established that a spouse's unemployment has a negative effect on the well-being of his/her partner, but this effect is smaller than the impact of own unemployment (Liem and Liem 1988). Moreover, the effect on the wellbeing of the partner seems to be asymmetric, i.e. the unemployment of the husband always results in a decline in wife's well-being, while the unemployment of the wife has a weaker effect, if any, on her husband's well-being (Winklemann and Winklemann, 1995; Kim and Do, 2013; Marcus, 2013).

11. There is also evidence that labour market insecurity is an important source of marital dispute and dissatisfaction with the partnership. Couples experiencing labour market insecurity, economic pressure, and financial strain may become angry, frustrated, and emotionally troubled. Individuals facing financial hardship can appear as less attractive partners to each other (Blood and Wolfe, 1960), and the strain on the family budget can lower the satisfaction that partners obtain from the relationship (Vinokour et al., 1996). For example, Broman et al. (1990) showed that auto workers who recently lost their job or were anticipating job loss, especially men in this situation, reported more conflict with their spouses than other workers. Similarly, Scherer (2009) showed that temporary workers in Europe were more likely to report disagreement with their partners compared to permanent employees.

\section{2c. Couples' joint labour market status and subjective well-being}

12. Labour supply decisions of individuals in a partnership are not independent of one another. The precise nature of this relation is, however, open to dispute. Different predictions can be made concerning the joint labour market status of couples based on the arguments in the literature. Standard neoclassical theory assumes that wives' labour force participation depends on husbands' employment status. Wives are expected to increase their labour supply as a result of husbands' loss of employment, a phenomenon called the "added worker effect". However, there is little empirical evidence supporting this effect in Britain, with most research indicating that wives of unemployed men are less likely to be employed (e.g. Davis et al 1992; McGinnity, 2002). Wives' disincentive to work can be explained by shared labour market conditions ("discouraged worker effect"). Therefore, both spouses rather than just one can find themselves in a situation of labour market insecurity. These dual-insecure couples not only face greater uncertainty and financial strain, but also suffer from exhaustion of their coping resources. It is hence plausible to expect that "dual-insecure" couples where both partners are in conditions of labour market insecurity have the lowest subjective well-being because they are more vulnerable than other couples.

13. In contrast, unemployment and precarious work can be regarded as a social norm and "hurt less" when there is more of it among relevant others. Clark (2003) found that unemployed Britons reported higher levels of well-being when their partner is also unemployed. There is also evidence that sometimes both partners in a couple deliberately remain out of work if the social security system to which they are entitled makes it financially worthwhile (McKee and Bell, 1985; McGinnity, 2002). Both benefit levels 
and the rules of the social support system determine the degree to which dual-insecure couples are financially better off than low-income working couples. The opposing expectation, then, is that dualinsecure couples are less likely to experience a decline in well-being than other couples, either because individuals feel less stigmatized or because they have access to a social benefit system when their partner is in a similarly insecure situation.

14. Finally, there is also evidence of a tendency among couples to avoid the "unemployed husbandemployed wife" situation. The presence of a working wife may lower the self-esteem of an unemployed husband (Barrere-Maurisson et al., 1985), as well as his sense of masculinity, authority, and pride (McKee and Bell, 1985). This effect could, in principle, also apply to the case of temporary employment: situations in which the husband works with a temporary contract while the wife has a permanent job could also lower the subjective well-being of individuals. Couples who find themselves in a "male-insecure" employment situation could suffer from a sharper decline in well-being. In addition to exposure to increased risk of financial difficulty, these couples could also face problems arising from "role-reversal" of spouses.

\section{2d. $\quad$ Research questions and hypotheses}

15. In the light of the discussion above, this paper investigates three related questions:

- First, do unemployment and temporary work have an impact on spouses' subjective wellbeing, and if so are their effects similar? With the rising incidence of temporary contracts in many OECD countries, there has been an on-going debate on whether temporary jobs are a better alternative to unemployment. While temporary jobs may be a stepping stone to good jobs, as some temporary workers eventually move to open-ended contracts, these jobs tend to leave individuals with poor career prospects and are associated with higher subjective job insecurity. If temporary jobs are indeed a better alternative to being unemployed, then temporary work should not hamper spousal well-being, at least to the same degree that unemployment does. On the contrary, spouses of temporary workers and of unemployed partners alike will suffer from lower well-being if temporary workers feel highly insecure and lack good career prospects. The first question seeks evidence for these alternative hypotheses.

- Second, to what extent does one's own employment status mitigate the negative impact on their subjective well-being of their spouses' labour market insecurity? Spousal labour market insecurity can be expected to hurt the most when individuals are themselves also either unemployed or in temporary jobs, as in these cases the couple faces remarkable economic strain during this stressful situation. Alternatively, spousal insecurity is less damaging when both spouses experience labour market insecurity, compared to the situation when only one spouse is unemployed or in temporary work because individuals in such couples may feel less "stigmatised" when both spouses are also in a similar situation. These couples facing dual-insecurity are also likely to be better informed of the social benefits to which they are entitled. Moreover, as men are still the main income-providers in many families, and gender roles are differentiated, the implications of female-insecurity for the well-being of employed husbands can be expected to be less severe than those for male-insecurity on employed wives' well-being. The second question explores the combinations of insecurity status at the couple level, and investigates its gendered impact on wives' and husbands' well-being.

- Third, is the impact of spousal labour market insecurity similar on the three subjective wellbeing outcomes? Subjective well-being encompasses reflective assessments on persons' lives, feelings and emotional states, and good psychological functioning. While these are clearly related to one another, psychological well-being is mainly related to affective states and good psychological functioning (Huppert 2009), whereas life and partnership satisfaction are related to 
evaluations that individuals make between a "standard" they perceive as appropriate for themselves and the actual circumstances of their life (Pavot and Diener et al. 1991). Based on these distinctions, different predictions can be made in relation to gender differences in subjective wellbeing outcomes and how spouses' well-being mediates the relationship.

16. Several considerations bear on the answers to these questions. First, the impact of spouses' labour market insecurity should a priori be greater in the case of wives' well-being than husbands' well-being (for all the three outcome variables considered). However the impact on husband's well-being may be mediated by wives' well-being. In other words, men could experience a drop in their subjective well-being upon wives' transition into labour market insecurity only as long as this deteriorates her well-being. Second, whether and to what extent husbands' well-being mediates the impact of labour market insecurity on wives' well-being may differ across subjective well-being outcomes. Satisfaction outcomes are more closely related to the gap between circumstances that are perceived as appropriate and actual conditions, thus a direct effect of husbands' labour market insecurity could be expected: women could experience a drop in their life and partnership satisfaction upon husbands' transition into labour market insecurity, irrespective of whether or not this leads to a drop in husbands' level of life and partnership satisfaction. On the contrary, psychological well-being of wives may depend on the change in husbands' psychological well-being as a response to unemployment or temporary work. Finally, partnership satisfaction is likely to be closely related to factors specific to the characteristics of the spouses and to the nature of the partnership, whereas life-satisfaction and psychological well-being have a wider range of determinants. The process linking spouses' employment status and subjective well-being can thus be expected to be the most profound for partnership satisfaction.

\section{The context of the United Kingdom}

17. Employment protection legislation (EPL), which encompasses both the labour market protection for permanent employees and the degree of regulation of the temporary employees, is crucial to understanding the degree of polarisation in the labour market. A more profound polarisation typically prevails in countries that adopt strong employment protection for permanent employees whilst allowing liberal use of temporary contracts. In these countries, due to smaller termination costs attached to temporary contracts, firms tend to substitute permanent workers with temporary ones. A large gap in job protection between permanent and temporary workers will reduce the conversion rate from temporary to open ended contracts, creating a duality in the labour market in which temporary employees are trapped in the periphery of the labour force (Boeri, 2011). On the contrary, polarisation will be less accentuated in countries with weak protection for permanent workers and flexible regulations with respect to workers with fixed-term contracts. Thus, the level of polarisation in the labour market depends on the nature of labour market regulation - i.e. on the rules relating to the hiring and firing of workers. Both the level of regulations concerning temporary contracts and the level of protection provided to permanent employees determine the degree of dualism in the labour market.

18. The research questions addressed by this paper are tested in the context of United Kingdom, a country characterised by a fairly flexible labour market with low level of polarisation. Figure 1 shows that the United Kingdom combines relatively light regulations on temporary contracts and weak protection for permanent employees. For instance, standard fixed-term contract and regular workers in United Kingdom are subject to relatively similar regulations with respect to the cost and difficulty of dismissals. The same definition of fair and unfair treatment applies for both groups. Also, fixed-term and regular workers alike are entitled to the same level of compensation and possibility of reinstatement following unfair dismissal. The length of trial period for both groups has to be agreed between the employer and the employee and the same notice and severance pay procedures apply to all (OECD, 2013 and 2014a). 
Figure 1. Employment protection legislation in the UK and the OECD average, 1985-2013

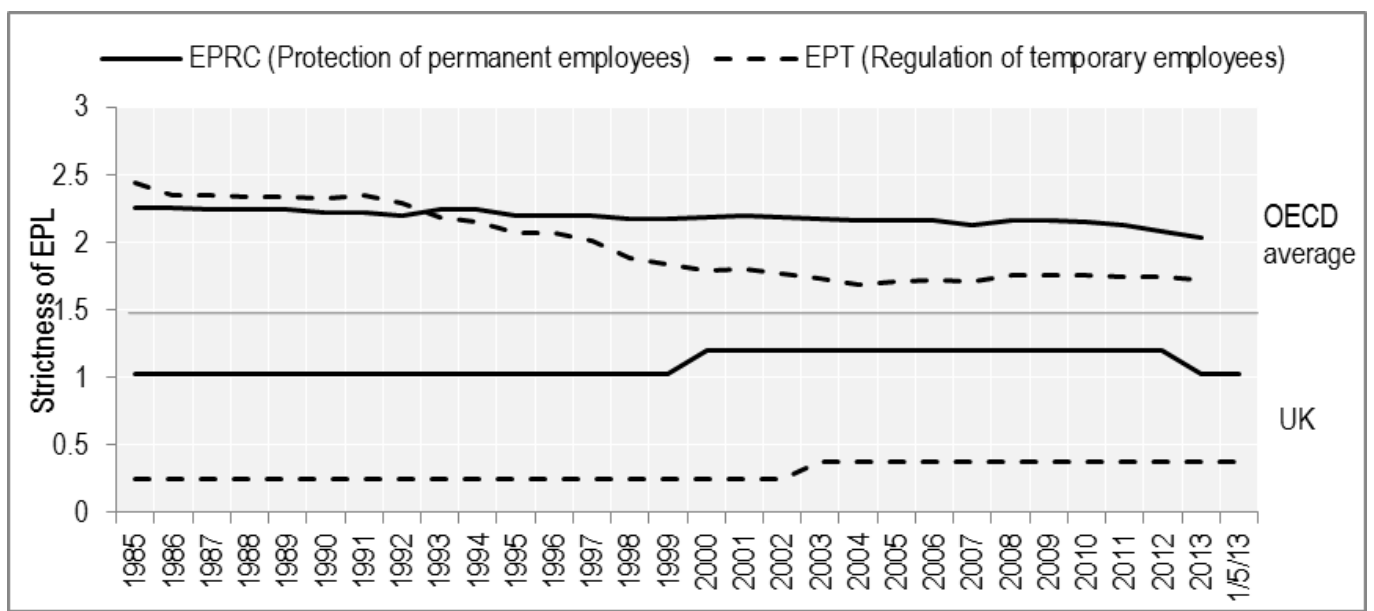

Notes: The OECD EPL indicator has two main dimensions. First, EPRC refers to the regulations governing individual or collective dismissal of regular workers and includes rules on notification procedures, length of notice period depending on job tenure, severance pay by tenure, definitions of justified and unfair dismissals. Second, EPT is the regulations on hiring and firing of temporary employees and includes rules on definitions for valid cases to use fixed-term contracts and for temporary working agencies (TWA's), maximum number of (cumulative) fixed-term contracts (and of TWA's), authorisation or reporting obligations for TWA's, and procedures of equal treatment of agency workers at the user firm (for details on the EPL indicators see OECD EPL database; OECD 2013). Each of these dimensions vary between 0 and 6, 0 indicating least restrictions and 6 indicating most restrictions in the regulation of temporary and protection of permanent employees.

Source: OECD EPL Database (http://www.oecd.org/els/emp/EPL-timeseries.xlsx)

19. In the period between 1985 and 2013, EPL in Britain remained relatively stable, at a lower level compared to the OECD average. However, this weak employment protection for permanent employees provided little incentive for employers to use temporary contracts extensively. The share of temporary workers remained very low around 5.5-7\% of all employees between 1992 and 2012 (Figure 2). Meanwhile, year to year transition rates from temporary jobs to permanent ones are relatively high compared, being at their lowest (37\%) between 1995 and 1996, and reached a peak of 57\% in 1998 and 1999 (Figure 3).

Figure 2. Percentage of temporary workers in the United Kingdom, 1983-2012

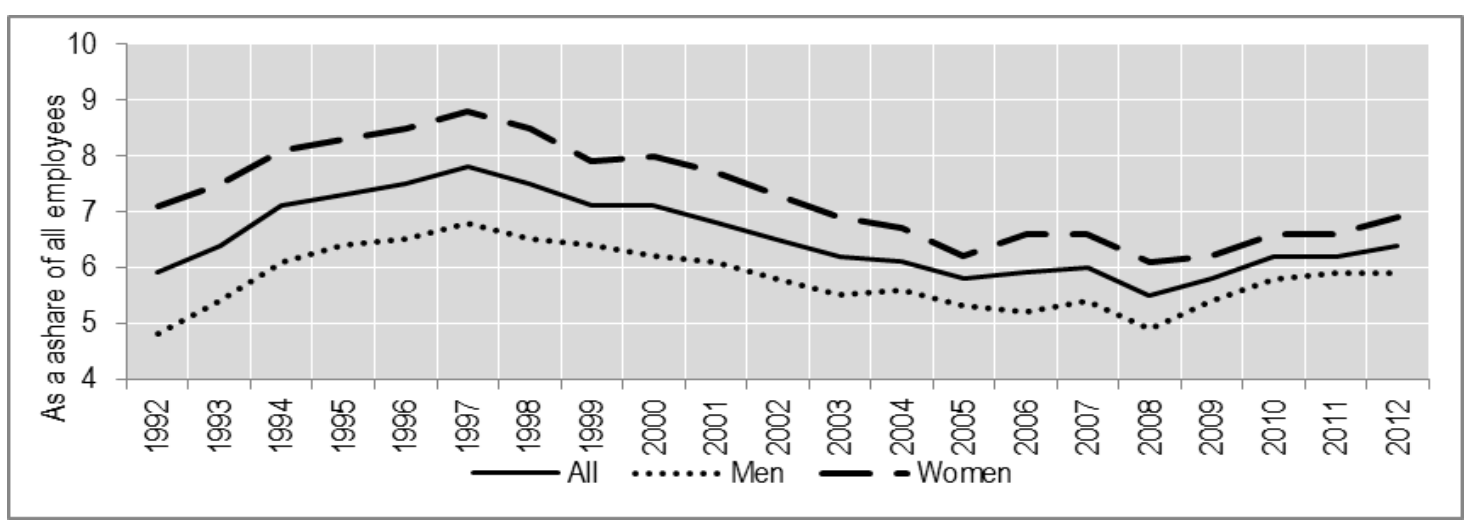

Data: Author's calculations using UK Labour Force Surveys, unweighted percentages. Source: UK Labour Force Surveys 
Figure 3. Year-to-year transition rates from temporary to permanent contracts in the United Kingdom, 19912008

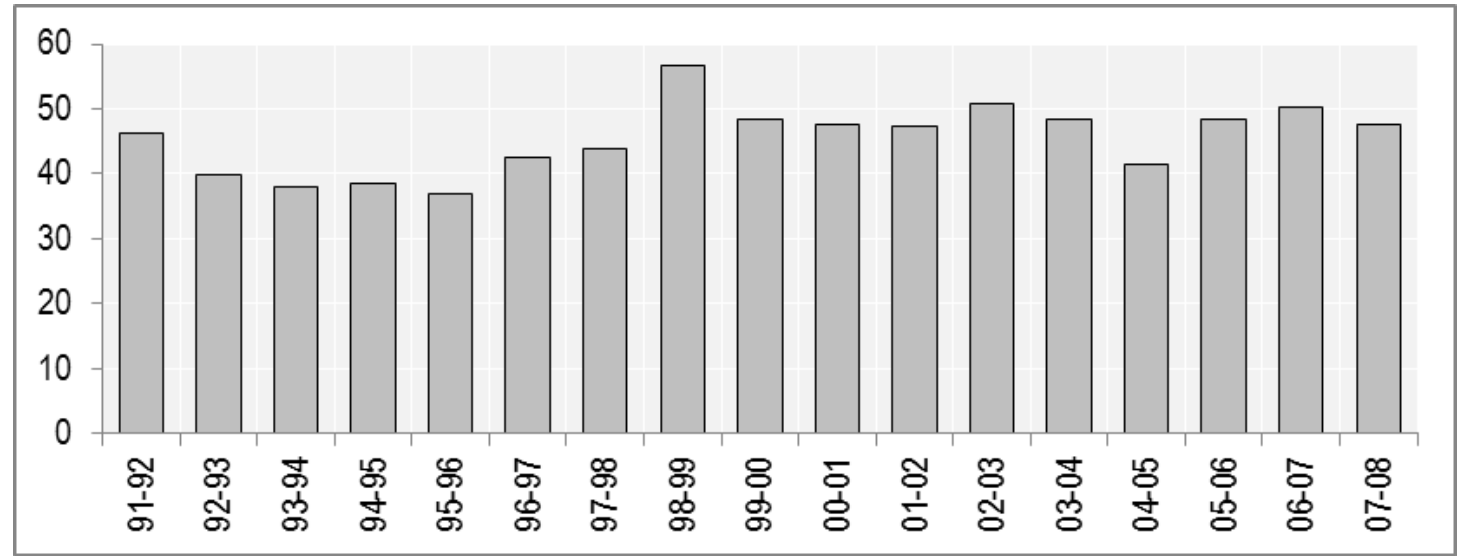

Notes: Transition rates are calculated between five states in $\mathrm{t}$ and $\mathrm{t}+1$ that include permanent employee, temporary employee, unemployed, out of labour force and student.

Source: Author's calculations using the panel waves of the British Household Panel Study.

20. These trends differ significantly from those observed in other OECD countries. For example in Spain, where the labour market is highly segmented, the share of temporary employees constituted one third of dependent employment between 1990s and mid-2000s. In Sweden, the share of temporary workers fluctuated between 14.5\% and 17.5\% between 1996 and 2014, while in Germany around 10-14.5\% of dependent employment consisted of temporary contract holders (OECD, 2015). In addition to the low share of temporary work observed in the United Kingdom, three-year transition rates from temporary to full-time permanent jobs among British temporary workers was $49 \%$ in 2011 , well above the levels observed in the Netherlands (16.5\%), Spain (20.5\%) and Ireland (25\%) (OECD, 2014). Overall, the labour market in the UK is less polarized than in other OECD countries, and temporary workers are more mobile than their counterparts elsewhere. Testing the spousal impact of temporary work in this context will provide a lower bound estimate, which could indicate more detrimental effect on spousal well-being of temporary workers in more segmented labour markets.

\section{Data, methods and variables}

\section{4a. The BHPS sample}

21. The analyses here draw upon the 18 waves of the British Household Panel Study, a yearly representative household survey started in 1991 that initially contained approximately 5,500 households and 10,300 individuals. The BHPS has detailed yearly data on employment position, partnership status, and subjective well-being outcomes, as well as many other socio-demographic variables. The analysis sample includes respondents aged between 20 and 65, who are either married or with a cohabiting partner and in heterosexual relationships. The respondents who appear in the panel only once are excluded from the sample. These restrictions yield a sample of 12,636 unique individuals (4,976 men and 5,217 women) who are observed 73,352 times in total over a mean of 5.8 years.

\section{$4 b \quad$ Measurement of variables}

Subjective well-being outcomes:

22. As subjective well-being is a multidimensional phenomenon, the paper focuses on three outcomes: psychological well-being, life satisfaction, and satisfaction from partnership. For psychological 
well-being, the analysis considers the 12-item version of the UK General Health Questionnaire: this index is based on 12 items that combine problems that respondents recently (over the last few weeks) had relating to concentration, loss of sleep, playing a useful role, being capable of making decisions, being constantly under strain, overcoming difficulties, enjoying day-to-day activities, being able to face problems, feeling unhappy or depressed, losing confidence, belief in self-worth, and general happiness. Respondents rate each item on a scale from 0 to 3, with 0 indicating "no problems" and 3 indicating "many more problems than usual". The Likert index of GHQ-12 summarizes scores from these 12 items and varies between 0 to 36 , with 0 representing the highest possible psychological well-being and 36 the lowest possible psychological well-being. In the analysis that follows, the scale of this indicator was reversed to make the interpretations more straightforward, i.e. higher values represent higher psychological well-being and vice versa.

Figure 4. Distribution of psychological well-being scores across respondents

Overall distribution in person-years, BHPS waves 1-18, individuals aged 20-65
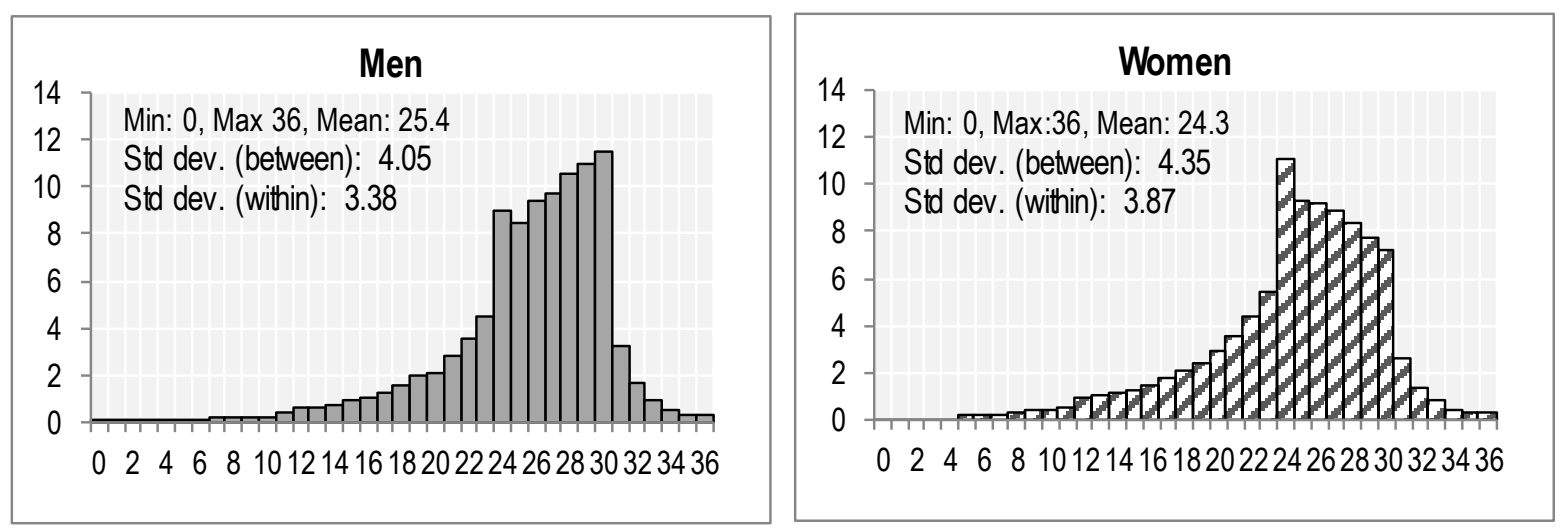

Source: Author's calculations with the British Household Panel Study, analysis sample only.

23. Life satisfaction is measured in the BHPS through the question "How satisfied or dissatisfied are you with your life overall", with the answer varying on a scale of 1 to 7 with the lowest value being "Not satisfied at all" and the highest value being "Completely satisfied". Partnership satisfaction is captured by the question "How satisfied or dissatisfied are you with your husband/wife/partner," and the answers are constructed the same way as with the life satisfaction item. 
Figure 5. Distribution of life satisfaction scores across respondents

Overall distribution in person-years,

BHPS waves 6-10 and 12-18, individuals aged 20-65
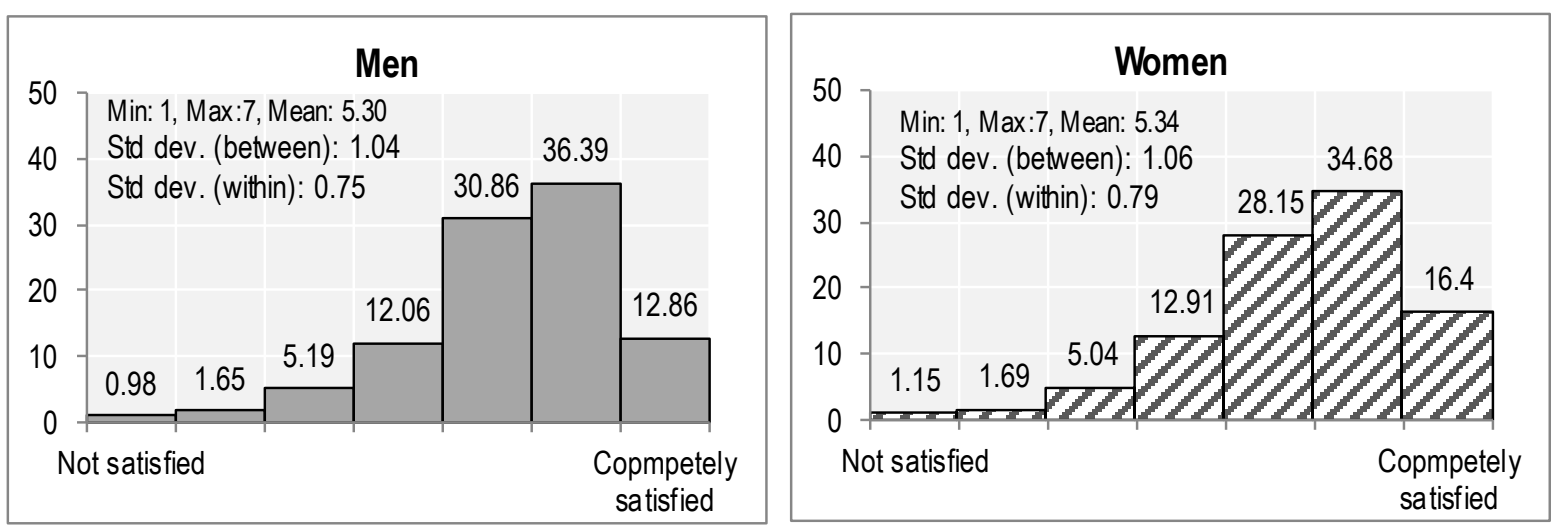

Source: Author's calculations with the British Household Panel Study, analysis sample only.

Figure 6. Distribution of partnership satisfaction scores across respondents

Overall distribution in person-years,

BHPS waves 6-10 and 12-18, individuals aged 20-65

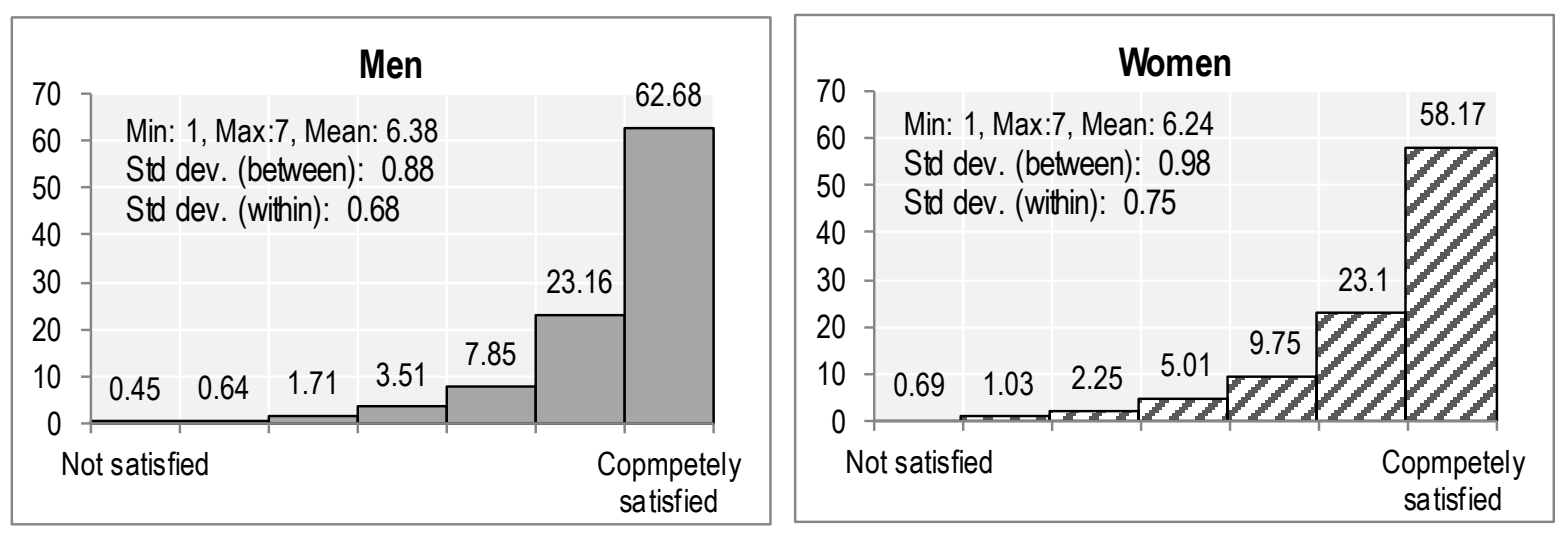

Source: Author's calculations with the British Household Panel Study, analysis sample only.

24. The three subjective well-being variables are converted to a 0 to 1 scale using min-max normalisation in order to be able to compare the magnitude of the coefficients across models. Note that satisfaction from partnership and life-satisfaction are available only in a limited number of waves, which results in different sample sizes for different types of analysis (these sample sizes are provided at the bottom of the tables with the estimation results).

\section{Labour market insecurity}

25. The variable summarising labour market insecurity is constructed by combining data on employment status and contract type, leading to a four-category indicator: i) permanent employee; ii) 
temporary employee; iii) unemployed; iv) out of labour force ${ }^{1}$. (Self-employees are excluded from the analysis as they represent a highly heterogeneous group.) Temporary employment refers to all workers with non-permanent contracts and includes seasonal work, fixed-term contracts, agency temping, seasonal and casual work. Unemployment is based on self-reported employment status, where respondents are asked to choose from a list what describes their current situation ${ }^{2}$. The same procedure is applied to derive the partner's labour market insecurity. Temporary work and unemployment measure labour market insecurity; people falling in these groups are compared with permanent employed and with each other in the multivariate models (see Annex A1 for the distribution of the sample by employment status).

\section{Control variables}

26. The models control for a number of variables that are found in the literature to be significantly related to subjective well-being among couples:

- In order to take account of spill-over effects within couples, partners' respective well-being outcome is included in the models, i.e. the partner's life satisfaction is controlled for in models on the life satisfaction of each person.

- $\quad$ Financial difficulty is measured with an item asking respondents how well they manage financially these days; those who find it difficult or very difficult are coded as facing financial difficulty.

- The impact of local labour markets is captured by regional unemployment rates, which are obtained on a monthly basis from the Office of National Statistics at NUTS-1 level and integrated in the data.

- $\quad$ Current duration of partnership is measured with a categorical variable which is composed with data on the duration of the relationship (first year, second year, third year, $4^{\text {th }}-5^{\text {th }}$ years, $6^{\text {th }}-10^{\text {th }}$ years and more than 10 years, with the first year is taken as the reference category).

- $\quad$ Presence and number of children are included as a categorical variable with following categories: No children, one child, two children and more than two children where "no children" is the reference category.

- $\quad$ Married and cohabiting individuals are differentiated with a dummy variable for cohabiting couples.

- Finally, variables for age, age squared and a time dummy (measured as the year of the panel) are controlled for in the analysis.

\section{4c. Panel data fixed effects models}

27. Both labour market status and spousal well-being can be influenced by an unobserved characteristic, for instance lack of commitment. A correlation between labour market position and the wellbeing of the spouse, then, would be caused by a correlation of each component with the unobserved lack of commitment rather than with each other: in this case, estimates would suffer from omitted variable bias since unobserved lack of commitment would bias the correlation between labour market position and spousal well-being. Fixed effects models are used to remove the unobserved heterogeneity by using within-

\footnotetext{
1 Spells in which individuals are out of labour force are included in the models but the results are not reported.

2 The response options include: self-employed, in paid-employment, unemployed, retired from paid work altogether, looking after family or home, full-time student, long-term sick or disabled, on maternity leave, on a government training scheme and something else.
} 
individual change over time in the independent and dependent variables (see, e.g., Hayashi, 2000; Hsiao, 2003; Wooldridge, 2002; and Brüderl, 2005). In other words, the fixed effects models use the changes in the independent variables (here labour market position) to predict the changes in the dependent variable (here subjective well-being outcomes).

\section{Box 1. Robustness checks}

Fixed-effects models are based on the assumption that unobserved individual heterogeneity is time-invariant; thus these models do not provide coefficients for time-constant variables such as gender. The alternative random effects models do estimate these coefficients for time-constant variables, but assume that the individual-specific error term is not correlated with the explanatory variables, thus allowing time-constant variables to play a role as explanatory variables. To test this assumption a Hausman test was computed to compare fixed- and random-effects under the null hypothesis that the individual effects are uncorrelated with other regressors in the models. This test suggests that a random effect model produces biased estimates, hence only estimates from fixed-effects models are reported below.

The subjective well-being outcomes used in the paper are neither strictly continuous variables nor strictly ordinal. The psychological well-being outcome runs on a 0 to 36 scale whereas the satisfaction outcomes run on a shorter scale, from 1 to 7 . Three alternatives are available in modelling these outcomes: Treat them as ordinal and estimate ordered regression models such as ordered logistic, dichotomise them and estimate logistic regressions or treat them as continuous variables and estimate linear models. The first option requires the fulfilment of the proportionality assumption that the coefficients for relationship between the dependent and the independent variables must be the same between each category of the dependent variable. The second option reduces the variation in the data and requires identifying a random cut-off point ${ }^{3}$. Because linear models are more intuitive to interpret and allow comparing the size of the coefficients across well-being outcomes by standardizing them between $0-1$, and due to the drawbacks of the second and third option, in the analysis below the outcome variables are treated as continuous and estimated through a linear fixed-effect models ${ }^{4}$.

28. Formal model for linear panel data fixed effects can be written as:

$$
y_{i t}-\bar{y}_{l}=\beta^{\prime}\left(x_{i t}-\bar{x}_{l}\right)+u_{i t}-\bar{u}_{l}, \quad t=1,2, \ldots \ldots, T
$$

where $y_{i t}$ is the dependent variable for individual $i$ at time $t$ where $\mathrm{t}=1,2, \ldots . \mathrm{T}$; and $\bar{y}_{l}$ is the individual mean of the dependent variable. $\beta^{\prime}$ is the vector of independent variables $(x)$ at time $t$; and $\bar{x}_{l}$ is the individual mean of these variables. Note that since fixed effect transformation relies on the assumption that unobserved individual specific components are constant over time, time-demeaning the data on $\mathrm{y}$ and $\beta \mathrm{x}$ discards the unobserved heterogeneity, which might potentially be correlated with the observables. This way, the models will rule out the possibility of spouses of "unhappy" individuals' self-selecting into unemployment or temporary jobs ${ }^{5}$.

3 The mean score or $2 / 3$ points have been used as cut-off points in same studies based on the GHQ index but no standard cut-off point is available for the satisfaction variables).

$4 \quad$ A number of models were estimated to examine the implications of model choice on well-being outcomes. These models, which are presented in Annex A3 and A4, include: a linear fixed effects models; a linear random effects models; a pooled cross-sectional linear regressions with standard errors clustered by individual; a random effects ordered logistics regression; pooled cross-sectional ordered-logistic regression with standard errors clustered by individual; a fixed-effect logistic regression; a random effect logistic regression; and pooled cross-sectional logistic regression with clustered standard errors within individuals. Note that there is no agreed-upon and consistent method to fit fixed effect regression for ordinal data. The coefficients for labour market variables produced by these models are consistent in terms of the sign of the relationship, although the size of the coefficient varies.

$5 \quad$ All estimations were done using Stata 14. 


\section{Empirical results}

29. Three sets of equations are fitted for each of the three subjective well-being outcome variables and for women and men separately: $i$ ) a model with control variables and partners' employment status (model a), ii.) model (a) plus individuals' labour market status, in order to net out individuals' own labour market insecurity (model b), and iii.) model (b) plus partners' subjective well-being status in order to net out the mediating effect of spouses' well-being (model c).

\section{5a. Husbands' labour market insecurity and wives' subjective well-being}

30. Table 1 shows that husbands' unemployment has a negative effect on wives' subjective wellbeing for all three outcome variables, and that the magnitude of the effect on each outcome is broadly similar (models 1a, 2a and 3a). Husbands' temporary work lowers wives' psychological well-being and life satisfaction, but does not influence her partnership satisfaction. Moreover, the coefficients from additional model (third row in the table) that compares temporary work and unemployment suggests that the effect of husbands' unemployment and temporary work on wives' well-being are similar, as reflected by the insignificant coefficient. Therefore, there is evidence that temporary work, like unemployment, influences wives' well-being in a negative way.

31. The negative effect of husbands' labour market insecurity remains significant after other determinants of subjective well-being and wives' labour market status are controlled for (models $1 \mathrm{~b}, 1 \mathrm{c}$, $2 \mathrm{~b}, 2 \mathrm{c}, 3 \mathrm{~b}$ and $3 \mathrm{c}$ ). However, the negative impact of husbands' unemployment on the psychological wellbeing of wives disappears when husband's psychological well-being is controlled for (model 1c), suggesting that the detrimental effect of male unemployment on wives' psychological well-being is mediated by husband's psychological reaction to their unemployment experience. This result suggests that wives experience a decline in psychological well-being as a result of a spill-over effect from their husbands' psychological distress. This is not the case for temporary work (all models) and for life and partnerships satisfaction outcomes for unemployment (models $2 \mathrm{c}$ and $3 \mathrm{c}$ ). 


\section{STD/DOC(2016)4}

Table 1. Husbands' labour market insecurity and wives' subjective well-being, fixed-effect regressions

\begin{tabular}{|c|c|c|c|c|c|c|c|c|c|}
\hline & \multicolumn{3}{|c|}{ Psychological well-being } & \multicolumn{3}{|c|}{ Life satisfaction } & \multicolumn{3}{|c|}{ Satisfaction with partnership } \\
\hline & $1 \mathrm{a}$ & $1 \mathrm{~b}$ & $1 \mathrm{c}$ & $2 \mathrm{a}$ & $2 \mathrm{~b}$ & $2 \mathrm{c}$ & $3 a$ & $3 b$ & $3 \mathrm{c}$ \\
\hline \multicolumn{10}{|l|}{ Husband: } \\
\hline Temporary vs. permanent & $\begin{array}{l}-0.011 * * * \\
(0.003)\end{array}$ & $\begin{array}{l}-0.011 \text { *** } \\
(0.003)\end{array}$ & $\begin{array}{l}-0.011 \text { *** } \\
(0.003)\end{array}$ & $\begin{array}{l}-0.012 * * \\
(0.005)\end{array}$ & $\begin{array}{l}-0.013 * * \\
(0.005)\end{array}$ & $\begin{array}{l}-0.012 * * \\
(0.005)\end{array}$ & $\begin{array}{l}-0.005 \\
(0.005)\end{array}$ & $\begin{array}{l}-0.005 \\
(0.005)\end{array}$ & $\begin{array}{l}-0.005 \\
(0.005)\end{array}$ \\
\hline \multirow{2}{*}{ Unemployed vs. permanent } & $-0.016^{* * *}$ & $-0.014 * * *$ & -0.004 & $-0.016^{* * * *}$ & $-0.014 * *$ & $-0.010^{*}$ & $-0.012 * *$ & $-0.012 * *$ & $-0.011 * *$ \\
\hline & $(0.004)$ & $(0.004)$ & $(0.003)$ & $(0.006)$ & $(0.006)$ & $(0.006)$ & $(0.006)$ & $(0.006)$ & $(0.005)$ \\
\hline Temporary vs. unemployed $^{+++}$ & 0.005 & 0.003 & -0.007 & 0.005 & 0.002 & -0.002 & 0.007 & 0.007 & 0.006 \\
\hline \multicolumn{10}{|l|}{ Self: } \\
\hline \multirow[t]{2}{*}{ Temporary vs. permanent } & & $0.010 * * *$ & $0.011 * * *$ & & $0.017 * * *$ & $0.016 * * *$ & & $0.009^{*}$ & $0.008^{*}$ \\
\hline & & $(0.003)$ & $(0.003)$ & & $(0.005)$ & $(0.005)$ & & $(0.005)$ & $(0.005)$ \\
\hline \multirow[t]{2}{*}{ Unemployed vs. permanent } & & $-0.032 * * *$ & $-0.032 * * *$ & & -0.009 & -0.009 & & 0.007 & 0.003 \\
\hline & & $(0.005)$ & $(0.004)$ & & $(0.007)$ & $(0.007)$ & & $(0.007)$ & $(0.006)$ \\
\hline \multirow[t]{2}{*}{ Temporary vs. unemployed ${ }^{+}$} & & $0.041 * * *$ & $0.043^{* * *} *$ & & $0.026^{* * * *}$ & $0.026 * * *$ & & 0.002 & 0.005 \\
\hline & & $(0.005)$ & $(0.005)$ & & $(0.008)$ & $(0.008)$ & & $(0.008)$ & $(0.008)$ \\
\hline Husband's psycho. well-being & & & $0.005^{* * *}$ & & & & & & \\
\hline \multirow[t]{2}{*}{ Husband's life satisfaction } & & & & & & $0.020 * * *$ & & & \\
\hline & & & & & & $(0.001)$ & & & \\
\hline \multirow[t]{2}{*}{ Husband's partnership satisfaction } & & & & & & & & & $0.038 * * *$ \\
\hline & & & & & & & & & $(0.001)$ \\
\hline \multirow[t]{2}{*}{ Financial difficulty (d) } & $-0.069 * * *$ & $-0.068 * * *$ & $-0.060 * * *$ & $-0.074 * * *$ & $-0.074 * * *$ & $-0.068 * * *$ & $-0.028 * * *$ & $-0.029 * * *$ & $-0.025 * * *$ \\
\hline & $(0.003)$ & $(0.003)$ & $(0.003)$ & $(0.004)$ & $(0.004)$ & $(0.004)$ & $(0.004)$ & $(0.004)$ & $(0.004)$ \\
\hline \multirow[t]{2}{*}{ Local unemployment rate } & -0.001 & -0.001 & -0.001 & $-0.003^{*}$ & $-0.003 *$ & $-0.002^{*}$ & $0.002 *$ & $0.002 *$ & 0.002 \\
\hline & $(0.001)$ & $(0.001)$ & $(0.001)$ & $(0.001)$ & $(0.001)$ & $(0.001)$ & $(0.001)$ & $(0.001)$ & $(0.001)$ \\
\hline (Ref: 1st year in partnership) & & & & & & & & & \\
\hline 2nd year in relationship & $-0.005 *$ & $-0.005 *$ & -0.004 & $-0.011 * * *$ & $-0.011 * * *$ & $-0.009 * *$ & $-0.011 * * *$ & $-0.011 * * *$ & $-0.009 * *$ \\
\hline & $(0.003)$ & $(0.003)$ & $(0.003)$ & $(0.004)$ & $(0.004)$ & $(0.004)$ & $(0.004)$ & $(0.004)$ & $(0.004)$ \\
\hline 3rd year in relationship & $-0.008 * * *$ & $-0.008 * * *$ & $-0.006 * *$ & $-0.023 * * *$ & $-0.023 * * *$ & $-0.021 * * *$ & $-0.029 * * *$ & $-0.029 * * *$ & $-0.025 * * *$ \\
\hline & $(0.003)$ & $(0.003)$ & $(0.003)$ & $(0.004)$ & $(0.004)$ & $(0.004)$ & $(0.004)$ & $(0.004)$ & $(0.004)$ \\
\hline 4-5th years in relationship & $-0.011 * * *$ & $-0.012 * * *$ & $-0.010 * * *$ & $-0.030 * * *$ & $-0.030 * * *$ & $-0.027 * * *$ & $-0.039 * * *$ & $-0.039 * * *$ & $-0.035 * * *$ \\
\hline & $(0.003)$ & $(0.003)$ & $(0.003)$ & $(0.005)$ & $(0.005)$ & $(0.005)$ & $(0.005)$ & $(0.005)$ & $(0.005)$ \\
\hline $6-10$ th years in relationship & $-0.010 * * *$ & $-0.009 * * *$ & $-0.007 * *$ & $-0.038 * * *$ & $-0.038 * * *$ & $-0.034 * * *$ & $-0.053 * * *$ & $-0.054 * * *$ & $-0.047 * * *$ \\
\hline & $(0.003)$ & $(0.003)$ & $(0.003)$ & $(0.005)$ & $(0.005)$ & $(0.005)$ & $(0.004)$ & $(0.004)$ & $(0.004)$ \\
\hline $10+$ years in relationship & $-0.013 * * *$ & $-0.013 * * *$ & $-0.010 * *$ & $-0.049 * * *$ & $-0.049 * * *$ & $-0.043 * * *$ & $-0.078 * * *$ & $-0.079 * * *$ & $-0.069 * * *$ \\
\hline 1 child & 0.000 & 0.005 & 0.004 & 0.004 & 0.005 & 0.004 & $-0.017 * * *$ & $-0.022 * * *$ & $-0.018 * * *$ \\
\hline & $(0.004)$ & $(0.004)$ & $(0.004)$ & $(0.006)$ & $(0.006)$ & $(0.006)$ & $(0.005)$ & $(0.005)$ & $(0.005)$ \\
\hline 2 children & $0.008^{*}$ & $0.013 * * *$ & $0.012 * * *$ & -0.006 & -0.006 & -0.007 & $-0.021 * * *$ & $-0.028 * * *$ & $-0.020 * * *$ \\
\hline & $(0.004)$ & $(0.004)$ & $(0.004)$ & $(0.007)$ & $(0.007)$ & $(0.007)$ & $(0.006)$ & $(0.007)$ & $(0.006)$ \\
\hline $2+$ children & 0.003 & 0.008 & 0.008 & -0.011 & -0.011 & -0.010 & $-0.020 * *$ & $-0.028 * * *$ & $-0.018 *$ \\
\hline & $(0.006)$ & $(0.006)$ & $(0.006)$ & $(0.010)$ & $(0.010)$ & $(0.010)$ & $(0.010)$ & $(0.010)$ & $(0.010)$ \\
\hline Age & $-0.004 *$ & $-0.005 * *$ & -0.004 & $-0.007 * *$ & $-0.006^{*}$ & $-0.006^{*}$ & -0.005 & -0.004 & -0.003 \\
\hline & $(0.002)$ & $(0.002)$ & $(0.002)$ & $(0.003)$ & $(0.003)$ & $(0.003)$ & $(0.003)$ & $(0.003)$ & $(0.003)$ \\
\hline Age square & $0.000 * * *$ & $0.000 * * *$ & $0.000 * * *$ & $0.000 * *$ & $0.000 * *$ & $0.000 *$ & $0.000 * * *$ & $0.000 * * *$ & $0.000 * * *$ \\
\hline & $(0.000)$ & $(0.000)$ & $(0.000)$ & $(0.000)$ & $(0.000)$ & $(0.000)$ & $(0.000)$ & $(0.000)$ & $(0.000)$ \\
\hline Cohabiting (d) & -0.000 & -0.000 & -0.001 & $-0.012 * *$ & $-0.012 * *$ & $-0.011 * *$ & $-0.012 * *$ & $-0.012 * *$ & -0.006 \\
\hline & $(0.003)$ & $(0.003)$ & $(0.003)$ & $(0.005)$ & $(0.005)$ & $(0.005)$ & $(0.005)$ & $(0.005)$ & $(0.005)$ \\
\hline Constant & $0.807 * * *$ & $0.827 * * *$ & $0.672 * * *$ & $0.982 * * *$ & $0.973 * * *$ & $0.858 * * *$ & $1.043 * * *$ & $1.020 * * *$ & $0.756^{* * *} *$ \\
\hline & $(0.073)$ & $(0.073)$ & $(0.073)$ & $(0.116)$ & $(0.117)$ & $(0.116)$ & $(0.112)$ & $(0.112)$ & $(0.110)$ \\
\hline $\mathrm{N}$ & 53595 & 53424 & 53424 & 38219 & 38057 & 38057 & 37813 & 37813 & 37813 \\
\hline $\mathrm{n}$ & 7765 & 7762 & 7762 & 6787 & 6781 & 6781 & 6739 & 6739 & 6739 \\
\hline Within $\mathrm{R}^{2}$ & 0.021 & 0.023 & 0.046 & 0.02 & 0.02 & 0.033 & 0.023 & 0.023 & 0.065 \\
\hline Between $\mathrm{R}^{2}$ & 0.08 & 0.091 & 0.122 & 0.002 & 0.003 & 0.02 & 0.013 & 0.014 & 0.137 \\
\hline Overall $\mathrm{R}^{2}$ & 0.045 & 0.051 & 0.081 & 0.005 & 0.006 & 0.025 & 0.015 & 0.015 & 0.108 \\
\hline Rho & 0.495 & 0.493 & 0.489 & 0.63 & 0.627 & 0.62 & 0.592 & 0.592 & 0.57 \\
\hline
\end{tabular}

Notes: a. Reference category for categorical variables shown in parenthesis. b. Control variables in full models: Financial difficulty, Local Unemployment Rate, Partner's corresponding well-being indicator, Years spent in relationship, Presence of children, Age, Agesquared, Cohabitation dummy, and year dummy. c. Partnership satisfaction and Life satisfaction available only in waves $7-10$ and $12-$ 18.d. Coefficients for the year dummies and out of labour force are available upon request. Legend: ${ }^{*} p<0.05 ;{ }^{* *} p<0.01 ;{ }^{* * *} p<0.001$; (d): dummy variable, standard errors in parentheses. ${ }^{+++}$Coefficients in this row are from a separate estimation where the reference category is set to unemployment, where everything else remains the same.

Source: Author's calculations from the BHPS (waves 1-18) 


\section{5b. Wives' labour market insecurity and husbands' subjective well-being}

32. The results for husbands show that the relationship between labour market insecurity and spousal well-being is asymmetrical among men and women. Neither unemployed nor temporarily employed wives affect husbands' life satisfaction (models 5a-5c). Temporary work, compared to permanent work and unemployment, has a negative effect on husbands' psychological well-being only if it influences wives' psychological well-being (model 4c). There is no relationship between wives' temporary work and husbands' partnership satisfaction, but husbands of unemployed women tend to be more satisfied with their partnership compared to her having a permanent contract (model 6a-c). This gender asymmetry is further explored in the following subsection.

33. It should be stressed that these fixed-effect models represent the impact of within-individual differences in employment status on within-individual differences in well-being outcomes, concentrating on "switchers". For instance, pooled-cross sectional regression models (with clustered standard errors within individuals) take into account both within and between-differences and produce even larger (and statistically significant) negative coefficients for wives' well-being outcomes (Table A3). Not only husbands' transitions to labour market insecurity translate into a decline in wives well-being; but also, on average, wives of men who are unemployed or have a temporary job have lower well-being outcomes. Fixed-effect coefficients thus produce a lower-bound estimate of insecurity on spousal well-being ${ }^{6}$.

34. Note that all these coefficients are significant after controlling for a set of factors that the literature identifies as important determinants of subjective well-being outcomes among couples. Selfreported financial difficulty has a strong negative effect on all subjective well-being outcomes for both men and women. Partners' well-being is a strong predictor of individuals' own well-being, lending support to the spill-over process. Regional unemployment rate has a mild negative impact for wives' life satisfaction and satisfaction from partnership, however, does not have a statistically significant impact on their psychological well-being. The duration of relationship is also related to well-being outcomes: for both men and women, number of years spent in relationship lowers their subjective well-being. The presence and number of children are negatively associated with husbands' satisfaction from partnership, whereas mothers are less satisfied with their partnership than being childless, regardless of number of children. The presence of children does not have an influence on life satisfaction of women, but having two children decreases their psychological well-being as compared to having no children. Cohabiting partners are less satisfied with life and partnership, but they do not differ from married individuals with regards to psychological well-being. The coefficients for age and age-squared indicate that there is an inverse Ushaped relationship between age and psychological well-being, and between age and life satisfaction. Year dummies (not reported) explain some of the remaining variation in psychological well-being and, to a lesser extent, in life satisfaction.

Even though the statistical procedure applied in the paper rules out endogeneity problem (i.e. the spouses of unhappy individuals self-selecting into insecure labour market spells), it is still possible that causality runs the other way: "unhappy" individuals cause their spouses to lose their jobs or fail to be offered a permanent job possibly as a result of an emotional spill-over effect. The fundamental idea tested with fixed-effects models in this paper is that if a decline (an increase) in the well-being of an individual coincides with when their spouse moves from permanent employment (insecure state) to an insecure state (permanent employment) then we can conclude that spousal insecurity causes a decline in individuals' well-being. However, a decline in well-being could have taken place before the transition to insecurity state but after $\mathrm{t}-1$, and conceal reverse causality. The specifications in this paper are unable to address reverse causality thus could be overestimating the negative effect of insecurity on partners' subjective well-being. However, there is evidence in the literature showing that stronger effects are from unemployment to wellbeing, not the other way around (e.g. Diette et al. 2012). 
Table 2. Wives' labour market insecurity and husbands' subjective well-being, fixed-effect regressions

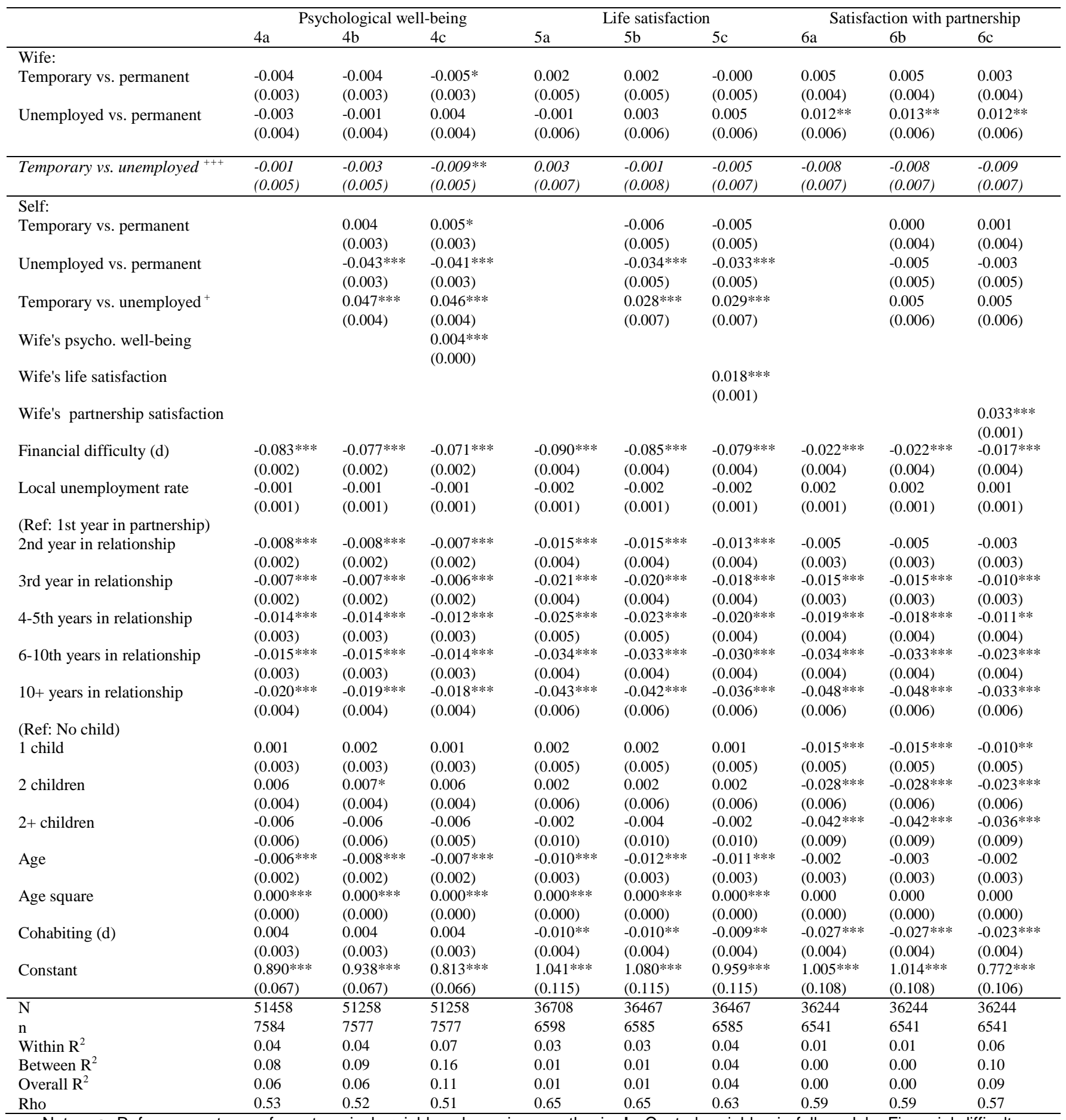

Notes: a. Reference category for categorical variables shown in parenthesis. b. Control variables in full models: Financial difficulty, Local Unemployment Rate, Partner's corresponding well-being indicator, Years spent in relationship, Presence of children, Age, Agesquared, Cohabitation dummy, and year dummy. c. Partnership satisfaction and Life satisfaction available only in waves 7-10 and 1218. d. Coefficients for the year dummies and out of labour force are available upon request. Legend: ${ }^{*} p<0.05 ;{ }^{* *} p<0.01 ;{ }^{* * *} p<0.001$; (d): dummy variable, standard errors in parentheses. ${ }^{+++}$Coefficients in this row are from a separate estimation where the reference category is set to unemployment, where everything else remains the same.

Source: Author's calculations from the BHPS (waves 1-18)

35. Additionally, all other things being equal and after the level of financial difficulty has been controlled, the estimates in Table 1 and Table 2 confirm that people's own employment status is still 
strongly associated with their subjective well-being outcomes. Among women, the highest subjective wellbeing scores are associated with temporary work, followed by permanent work, and unemployment. This is interesting considering their husbands' temporary work lowers wives' well-being (Table 1). Unemployment has a detrimental effect on husbands' own psychological well-being and life satisfaction compared to both temporary and permanent work (Table 2).

\section{5c. Couple employment dynamics and subjective well-being}

36. The results described in Tables 1 and 2 have shown the impact on wives' and husbands' subjective well-being of their spouses' labour market insecurity. This section shows that the extent to which spouse's labour market insecurity affects well-being differs by individuals' own employment status; however, the direction of the spousal effect differs across well-being outcomes. The impact of spouses' labour market insecurity is much greater for individuals who are themselves in labour market insecurity as opposed to having permanent jobs, with the differential effect of spousal unemployment being larger than the differential effect of temporary work. Broadly speaking, the effect of spousal labour market insecurity for individuals who are themselves in labour market insecurity is positive on psychological well-being and life satisfaction but negative on partnership satisfaction (Figure 7). On the contrary, among individuals with permanent jobs, spouses' temporary work and unemployment are associated with lower well-being among women, and higher well-being among husbands.

37. More specifically, the previous section had shown that husbands' labour market insecurity has a strong negative effect on wives' psychological well-being and life satisfaction (Table 2). However, Table 3 shows that this is not the case for women who experience insecurity themselves. In fact, for example, the psychological well-being of women with a temporary job is positively affected by male unemployment (0.035-0.011>0 in model 7a). Similarly, women who are either unemployed or have a temporary job experience an increase in life satisfaction due to husbands' unemployment $(0.052-0.012>0$ for temporarily employed wives and 0.060-0.021>0 for unemployed wives in model 7b).

38. While Table 2 showed that women's labour market insecurity has almost no impact on husbands' well-being outcomes, the interaction between wives' and husbands' labour market statuses (in Table 3) reveals that unemployed and temporarily employed husbands experience a sharp decline in psychological well-being if their wives have permanent jobs (0.024-0.009>0 and 0.040-0.001>0 in model 8a). Results are similar among male temporary employees: they score higher in psychological well-being $(0.021-0.009>0$ in model 8a) and life satisfaction (0.025-0.005>0 in model $8 \mathrm{~b}$ ) when their wives are temporary employees rather than permanent employees. Men who themselves experience labour market insecurity have lower psychological well-being and life-satisfaction when they are partnered with female permanent employees. 
Figure 7. Couples' joint labour market insecurity and subjective well-being

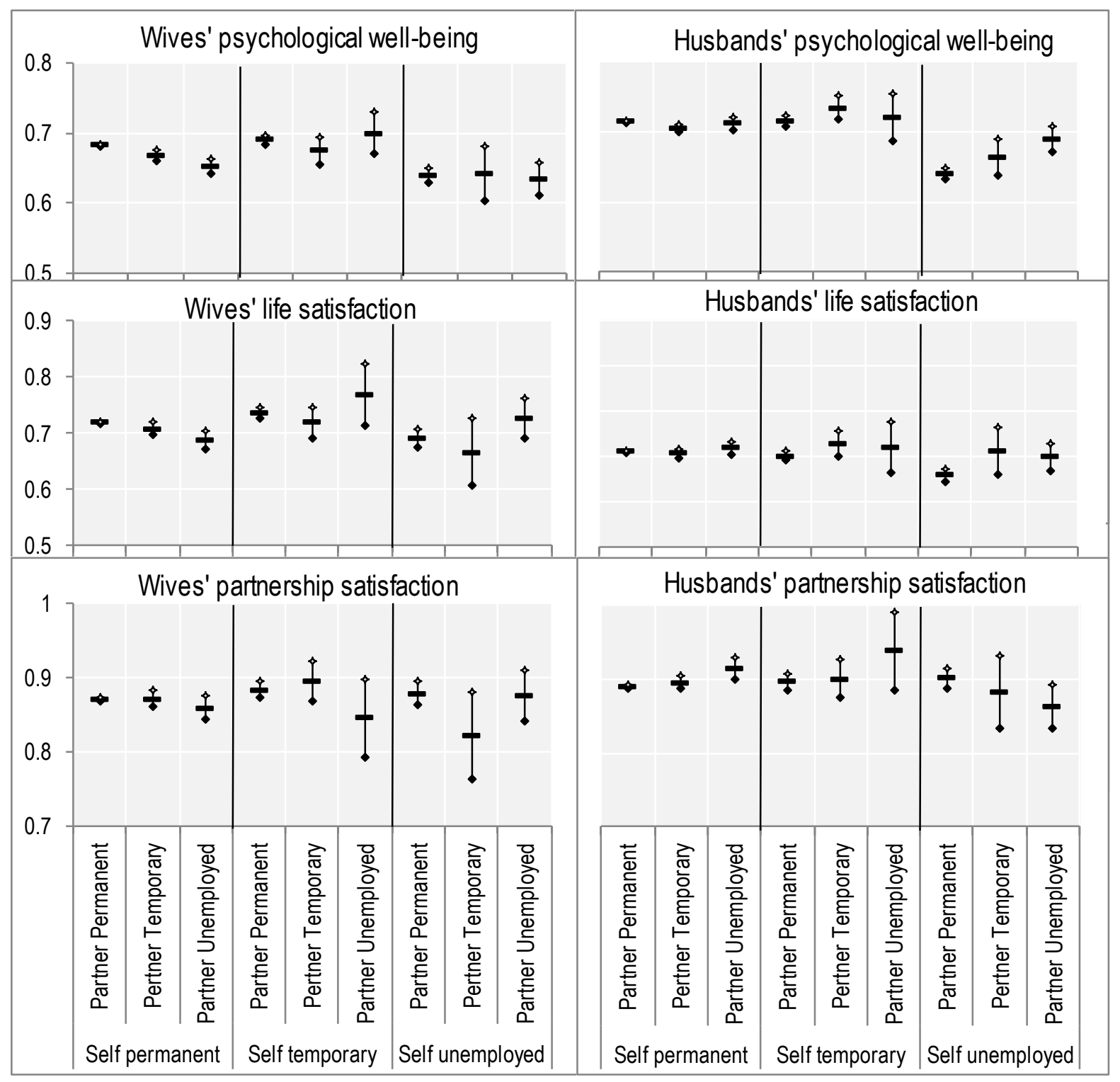

Notes: Marginal effects of interaction terms from fixed-effect models.

Source: Author's calculations from the BHPS (waves 1-18) 
Table 3. Subjective well-being and labour market insecurity at the couple level

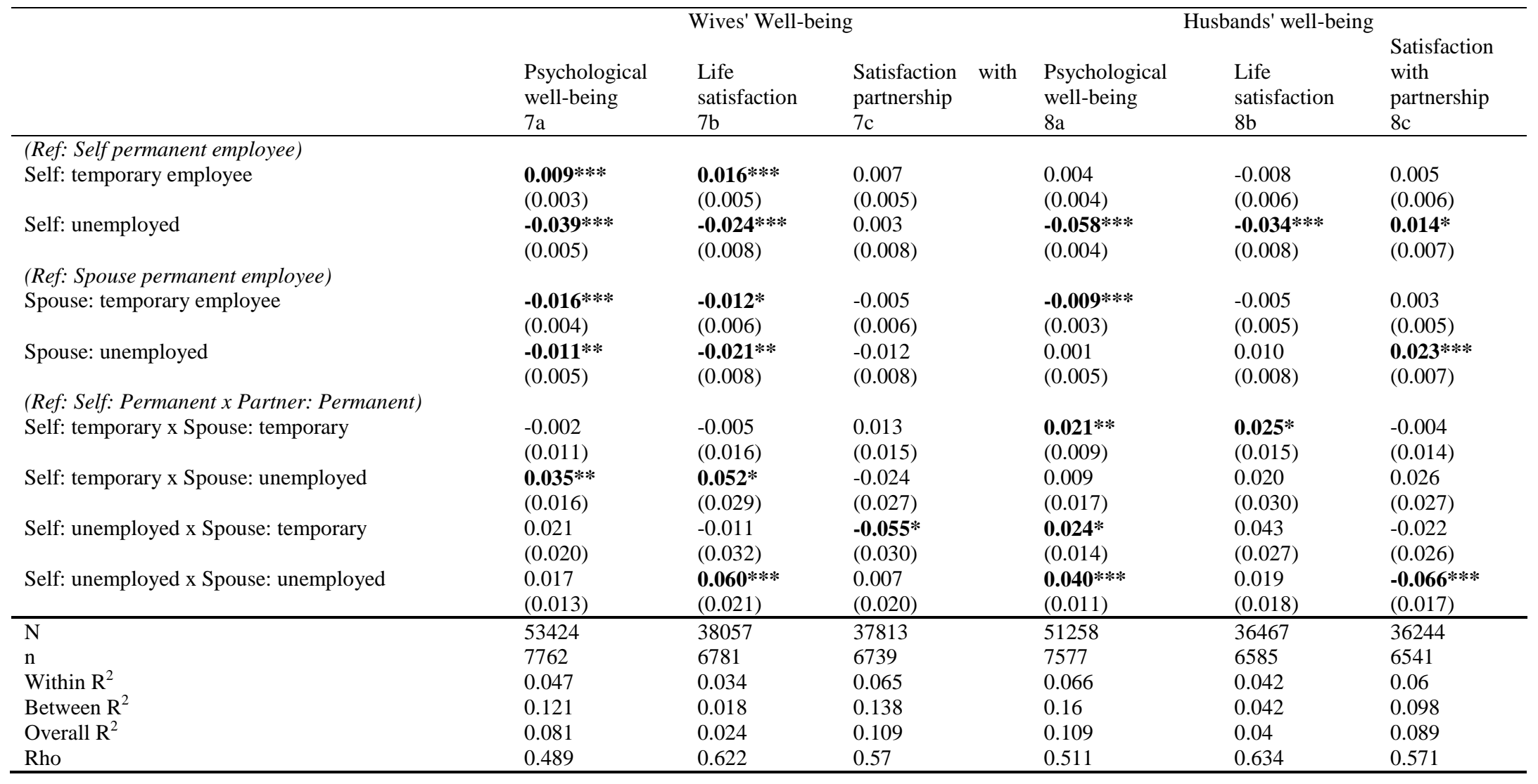

Notes: a. Reference category for categorical variables shown in parenthesis. b. Control variables in full models: Financial difficulty, Local Unemployment Rate, Partner's corresponding well-being indicator, Years spent in relationship, Presence of children, Age, Age-squared, Cohabitation dummy, and year dummy. c. Partnership satisfaction and Life satisfaction available only in waves $7-10$ and $12-18$. Legend: ${ }^{\star} p<0.05 ;{ }^{* *} p<0.01 ;{ }^{* * *} p<0.001$. Standard errors in parentheses. 
39. Finally, with respect to partnership satisfaction, the negative effect of husbands' unemployment is broadly the same for all women, whether they are permanently employed, temporarily employed or unemployed (positive significant effect in models 3a-c versus insignificant coefficient in model 7c). However, husbands' temporary work, which had no direct effect on wives' partnership satisfaction in models $3 \mathrm{a} 3 \mathrm{~b}$ and $3 \mathrm{c}$, nonetheless has a large negative effect on wives' partnership satisfaction when the wife herself is unemployed $(-0.055-0.005<0$ in model 7c). Among men, Table 2 showed that wives' unemployment was associated with higher partnership satisfaction (models 6a-c). However, this is not the case when husbands themselves are also unemployed, reflected by the interaction term "unemployed*wife's unemployed" in Table 3 is negative $(-0.066+0.023<0)$.

\section{Conclusion and discussion}

40. This paper addressed three interrelated questions regarding the impact of labour market insecurity of partners within a couple. First, whether temporary work has a similar negative effect on spousal subjective well-being as unemployment does. Second, whether and to what extent the labour market status of one partner moderates the negative impact on their subjective well-being stemming from labour market insecurity of the other partner. Third, whether the impact of spousal labour market insecurity differ across different aspects of subjective well-being.

41. With respect to the first question, the analyses in this paper show that both temporary work and unemployment experienced by the male partner had a negative impact on the subjective well-being of the female partner. The paper thus establishes an empirical link between temporary work and spousal wellbeing which is broadly similar to the well-established link between unemployment and spousal well-being. The empirical analysis also indicates some differences in the way in which unemployment and temporary work affect spousal well-being. Unlike unemployment, temporary work of the male partner does lower wives' partnership satisfaction; similarly, temporary work of the female partner does not raise husbands' partnership satisfaction.

42. As regard to the second question (the moderating effect of individuals' own labour market status), the analysis shows that the impact of temporary work (as that of unemployment) on spousal wellbeing differs depending on the employment status of the spouse in question. All other things being equal, and after controlling for the level of financial difficulty reported by the couple, women with permanent jobs are hurt more by husbands' labour market insecurity, whereas the unemployed husbands of women in employment have the lowest psychological well-being and life-satisfaction scores. These results suggest that the psychological well-being and life-satisfaction of coupled individuals are lowered the most when men are economically dependent on their female partners: in other terms, it is role-reversal, rather than dual insecurity, that generates familial distress ${ }^{7}$. Thus, a second contribution of the paper is to highlight the relationship between spousal well-being and insecurity when the couple is used as unit of analysis.

43. On the third question, the analysis indicates that labour market insecurity affects the three wellbeing outcomes in different ways. First, the effects of labour market insecurity on partnership satisfaction differ from those on psychological well-being and life-satisfaction: while wives' unemployment is associated with higher partnership satisfaction for husbands, it does not affect husbands' psychological well-being and life satisfaction. Moreover, dual-insecurity leads to a decline in partnership satisfaction, whereas male-insecurity is associated with higher psychological well-being and life-satisfaction. Second, differences in the impacts of labour market insecurity on subjective well-being outcomes reflect the mediating effect of the spill-over process between spouses' well-being outcomes. The change in psychological well-being in relation to spousal labour market insecurity is mediated by spousal

7 However, in the case of partnership satisfaction, dual insecurity is the main factor at work: individuals' partnership satisfaction tends to drops when one or both partners either unemployed or temporary workers. 
psychological well-being; this mediating effect of spousal well-being on individuals' well-being is absent for satisfaction outcomes. These results highlight the importance of using a multi-dimensional approach when investigating subjective well-being outcomes, as the direction of the relationship (as well as the mediating and moderating factors between well-being and other explanatory variables) may differ from one well-being outcome to the other.

44. The empirical results presented in this paper have two limitations, one concerning the conceptualisation of temporary work and unemployment, and the other concerning the measurement of subjective well-being. First, temporary work and unemployment have been defined here in a broad manner, ignoring different types of non-permanent employment or unemployment of different duration; introducing these distinctions would have resulted in very small number of observations. In the United Kingdom, fixed-term contracts are more secure than casual and seasonal contracts as well as agency work, which are shorter-term arrangements. Also, various types of temporary contracts differ in terms of their intrinsic job quality (Inanc, 2015). By grouping various contract-types together, the paper does not shed light on the specific mechanisms (e.g. the peripheral location of temporary workers in the job market, the inferior quality of these jobs, the employment strain arising from the demands of performing well in the current job whilst looking for a different one) linking temporary work and spousal well-being. This is an important avenue for further research.

45. Second, the psychological well-being measure used here is based on GHQ questions, which ask respondents whether they recently experienced problems such as loss of sleep or being unable to concentrate. This raises the issue of whether it is appropriate to extrapolate answers to these questions on a yearly basis. Further, since these questions ask respondents to rate how they feel compared to how they usually feel, they might underestimate chronic conditions. For instance, if a person has been unemployed for a long time and does not feel more depressed than usual anymore, the item may not capture the fluctuation in their well-being.

46. Despite these shortcomings, the evidence presented here has some policy implications. Analysing the subjective well-being of both partners in a couple is important because stressful situations such as labour market insecurity experienced by one partner has both a direct effect on the well-being of the individual experiencing it and an indirect effect on the well-being of the other partner. Considering the well-being of both partners in a couple is both interesting in itself and can play a role in other domains of family life such as fertility decisions or the likelihood of separation and divorce. For these reasons, from a policy perspective, the broader implications of labour market insecurity should be carefully considered. Welfare policies, especially those geared to buffer the negative effect of labour market risks on individuals, can improve the well-being of all family members. There is evidence that the generosity of unemployment benefits reduces overall insecurity and improves subjective well-being (e.g. Inanc and Kalleberg, forthcoming; Boarini et al., 2013), including that of housewives (Sjöberg, 2010). This implies that unemployment benefits and other welfare policies may have external benefits that reach beyond the immediate beneficiary ${ }^{8}$.

47. Finally, evidence that temporary work has a negative impact on spousal well-being similar to that of unemployment is important because the labour market in the United Kingdom is relatively flexible, with frequent transitions from unemployment and temporary work to open ended contracts. Temporary employees in the United Kingdom are also a heterogeneous group, with many having tertiary education and being employed in managerial positions. In more segmented labour markets, with a sharper divide between the "core" and the "periphery", the consequences of labour market insecurity on other household

$8 \quad$ However, these policies may not fully offset the well-being costs of insecurity, as a large part of these costs are non-pecuniary (e.g. Winkelmann and Winkelmann, 1995) and their effects scar individuals for a long time. 


\section{STD/DOC(2016)4}

members could be even more severe. This suggests that a fuller picture of the implications of labour market flexibility needs to take into account of effects of all family members, rather than just concentrating on employment outcomes for individual workers. 


\section{REFERENCES}

Aronsson, G., K. Gustafsson and M. Dallner (2002), "Work environment and health in different types of temporary jobs", European Journal of Work and Organisational Psychology, 11(2), pp. 151-175.

Artazcoz, L., J. Benach, C. Borrell and I. Cortès (2005), "Social inequalities in the impact of flexible employment on different domains of psychosocial health", Journal of Epidemiology \& Community Health, 59, pp. 761-67.

Banks, M.H. and P.R. Jackson (1982), "Unemployment and risk of minor psychiatric disorder in young people: cross sectional and longitudinal evidence", Psychological Medicine, 12, pp. 789-98.

Barrère-Maurisson, M.A., F. Battagliola, and A.M. Daune-Richard (1985), "The Course of Women's Careers and Family Life" in (Eds) B. Roberts, F. Finnegan and D. Gallie, New Approaches to Economic Life, Manchester University Press.

Blood, R.O. and D.M. Wolfe (1960), Husbands and wives: The dynamics of family living, the Free Press, New York.

Boarini, R., M. Comola, F. de Keulenaer, R. Manchin and C. Smith (2013), "Can governments boost people's sense of well-being? The impact of selected labour market and health policies on life satisfaction", Social Indicators Research, 114, pp. 105-120.

Boeri, T. (2011), "Institutional Reforms and Dualism in European Labor Markets", in O. Ashenfelter and D. Card (eds.), Handbook of Labor Economics, pp. 1173-1236, Elsevier, Amsterdam.

Broman, C.L., V. Lee Hamilton, and W.S. Hoffman (1990), "Unemployment and Its Effects on Families: Evidence from a Plant Closing Study", American Journal of Community Psychology, 18(5), pp. 643-59.

Clark, A.E. (2003), "Unemployment as a social norm: Psychological evidence from panel data", Journal of Labor Economics, 21, pp. 323-51.

Clark, A.E. and A.J. Oswald (1994), “Unhappiness and Unemployment”, Economic Journal 104(424), pp. 648-59.

Davies, R.B., P. Elias and R. Penn (1992), “The relationship between a husband's unemployment and his wife's participation in the labour force", Oxford Bulletin of Economics and Statistics 54(2), pp. 145-71.

De Witte, H. and K. Naswall (2003), "Objective versus subjective job insecurity: consequences of temporary work for job satisfaction and organisational commitment in four European countries", Economic and Industrial Democracy, 24(2), pp. 149-188.

Dierner E., E. Suh, R. Lucas and H. Smith (1999), "Subjective well-being: Three decades of progress", Psychological Bulletin, 125(2), pp. 276-302.

Frey, B.S. and A. Stutzer (2002), "What can Economists Learn from Happiness Research", Journal of Economic Literature, 40(2):402-35. 
Green, F. (2011), "Unpacking the misery multiplier: how employability modifies the impacts of unemployment and job insecurity on life satisfaction and mental health", Journal of Health Economics, 30(2), pp. 265-76.

Hall, R. (2006), "Temporary agency work and HRM in Australia: cooperation, specialisation and satisfaction for the good of all", Personnel Review, 35(2), pp. 158-174.

Hayashi, F. (2000), Econometrics, Princeton University Press, Princeton, NJ and Oxford, UK.

Heady, P. and M. Smyth (1989), Living Standards during Unemployment: A Report of a Survey of Families Headed by Unemployed People, H.M.S.O, London.

Hsiao, C. (2003), Analysis of panel data, Cambridge, UK, Cambridge University Press.

Hupert, F.A. (2009), "Psychological Well-being: Evidence Regarding its Causes and Consequences" Applied Psychology: Health and Well-being, 1(2):137-164, doi:10.1111/j.1758-0854.2009.01008.x

Inanc, H. (2015), “Temporary Work and Job Quality", in Unequal Britain at Work edited by (Eds) Alan Felstead, Duncan Gallie and Francis Green, Oxford: Oxford University Press.

Inanc, H., Y. Zhou, D. Gallie, A. Felstead and F. Green (2015), "Direct Participation and employee learning at work", Work and Occupations, DOI: 10.1177/0730888415580650.

Inanc, H. and A. Kalleberg (Forthcoming), "Insecurity and subjective well-being in Europe", unpublished manuscript.

Jackson, P.R., and P.B. Warr (1984), "Unemployment and psychological ill-health: the moderating role of duration and age", Psychological Medicine 14, pp. 605-614.

Jahoda, M. (1982), Employment and Unemployment, A Social-Psychological Analysis, Cambridge: Cambridge University Press.

Kahneman, D., E. Diener and N. Schwarz (1999), Well-being: The Foundations of Hedonic Psychology, New York: Russell Sage Foundation.

Lewchuk, W., M. Clarke and A. de Wolff (2008), "Working without commitments: precarious employment and health", Work, Employment and Society, 22(3), pp. 387-406.

Liem, R. and J.H. Liem (1988), "Psychological Effects of Unemployment on Workers and Their Families", Journal of Social Issues 44(4), pp. 87-105.

McGinnity, F. (2002), "The Labour Force Participation of the Wives of Unemployed Men: Comparing Britain and Germany Using Longitudinal Data", European Sociological Review 18(4), pp. 473488.

McKee, L. and C. Bell (1985), Marital and Family Relations in Times of Male Unemployment: Manchester University Press.

Murphy, G.C. and J.A. Athanasou (1999), "The effect of unemployment on mental health", Journal of Occupational and Organizational Psychology 72, pp. 83-99.

Nordenmark, M. and M. Strandh (1999), “Towards a Sociological Understanding of Mental Well-Being 
among the Unemployed: The Role of Economic and Psychosocial Factors", Sociology 1999(33), pp. 577-97.

OECD (2015), Employment Protection Legislation Dataset, http://www.oecd.org/els/emp/EPLtimeseries.xlsx

OECD (2015), Labour Force Statistics, Permanent Temporary Employment, Online Dataset, https://stats.oecd.org/Index.aspx? DataSetCode=TEMP I

OECD (2014), OECD Employment Outlook 2014, "Non-regular Employment, Job Security and the Labour Market Divide", Chapter 3, OECD Publishing.

OECD (2013), OECD Guidelines for Measuring Subjective Well-being, OECD Publishing. http://dx.doi.org/10.1787/9789264191655-en

Pavot, W., E. Diener, C.R. Colvin, and E. Sandvik (1991), "Further validation of the satisfaction with life scale: Evidence for the cross-method convergence of well-being measures", Journal of Personality Assessment, Vol. 57(1), pp. 149-161.

Rodriguez, E. (2002), "Marginal employment and health in Britain and Germany: Does unstable employment predict health?”, Social Science \& Medicine 55, pp. 963-79.

Scherer, S. (2009), “The Social Consequences of Insecure Jobs”, Social Indicators Research 93, pp. 52747.

Sjöberg, O. (2010), "Social Insurance as a Collective resource: Unemployment benefits, job insecurity and subjective well-being in a comparative perspective", Social Forces, 88(3), pp. 1281-1304.

Stiglitz, J.E, A. Sen, and J.P. Fitoussi (2008), Report by the Commission on the Measurement of Economic Performance and Social Progress.

Vinokur, A.D., R.H. Price, and R.D. Caplan (1996), "Hard Times and Hurtful Partners: How Financial Strain Affects Depression and Relationship Satisfaction of Unemployed Persons and Their Spouses", Journal of Personality \& Social Psychology 71, pp. 166-79.

Virtanen, M., M. Kivimäki, M. Joensuu, P. Virtanen, M. Elovainio, and J. Vahtera (2005), "Temporary employment and health: a review", International Journal of Epidemiology 34(3), pp. 610-22.

Warr, P. (1987), Work, Unemployment, and Mental Health, Oxford: Clarendon Press.

White, M. (1991), “Against unemployment”, Policy Studies Institute, London.

Winkelmann, L., and R. Winkelmann (1995), "Happiness and Unemployment: A Panel Data Analysis for Germany”, Economics Quarterly 41(4), pp. 293-307.

Wooldridge, J.M. (2009), Introductory Econometrics: A Modern Approach, Mason, South-Western. 


\section{ANNEX}

Table A1. Distribution of the BHPS sample by employment status, Waves 1-18

\begin{tabular}{lcccccccc}
\hline & \multicolumn{3}{c}{ Overall } & \multicolumn{3}{c}{ Husbands } & \multicolumn{3}{c}{ Within individuals } & \multicolumn{2}{c}{ Overall } & \multicolumn{2}{c}{ Within individuals } \\
& $\mathrm{N}$ & $\%$ & $\mathrm{n}$ & $\%$ & $\mathrm{~N}$ & $\%$ & $\mathrm{n}$ & $\%$ \\
\hline Permanent employee & 42020 & 79.02 & 6484 & 84.31 & 34513 & 61.8 & 5952 & 74.71 \\
Temporary employee & 2066 & 3.88 & 1135 & 14.76 & 2261 & 4.05 & 1212 & 15.21 \\
Unemployed & 2394 & 4.5 & 1247 & 16.21 & 1029 & 1.84 & 767 & 9.63 \\
Inactive & 6351 & 11.94 & 1798 & 23.38 & 17497 & 31.33 & 4251 & 53.36 \\
Student & 348 & 0.65 & 247 & 3.21 & 546 & 0.98 & 354 & 4.44 \\
Total & 53179 & 100 & $7691^{*}$ & & 55846 & 100 & $7967 *$ & \\
\hline
\end{tabular}

* Total of unique individuals in the sample. 
STD/DOC $(2016) 4$

Table A2. Labour market insecurity among couples and subjective well-being outcomes, descriptive statistics, BHPS Waves 1-18

\begin{tabular}{|c|c|c|c|c|c|c|c|c|c|c|c|c|}
\hline \multirow{3}{*}{ Psychological well-being } & \multicolumn{6}{|c|}{ His well-being } & \multicolumn{6}{|c|}{ Her well-being } \\
\hline & \multirow[b]{2}{*}{ mean } & \multicolumn{3}{|c|}{ STD } & \multirow[b]{2}{*}{$\mathrm{N}$} & \multirow[b]{2}{*}{$\mathrm{n}$} & \multirow[b]{2}{*}{ mean } & \multicolumn{3}{|c|}{ STD } & \multirow[b]{2}{*}{$\mathrm{N}$} & \multirow[b]{2}{*}{$\mathrm{n}$} \\
\hline & & overall & between & within & & & & overall & between & within & & \\
\hline He's permanent \& She's permanent & 25.98 & 4.33 & 3.57 & 3.10 & 30031 & 5472 & 24.77 & 5.02 & 3.93 & 3.69 & 30185 & 5551 \\
\hline He's permanent \& She's temporary & 25.47 & 4.76 & 4.32 & 2.57 & 1777 & 1019 & 24.86 & 5.12 & 4.96 & 2.64 & 1784 & 1024 \\
\hline He's permanent \& She's unemployed & 26.14 & 4.39 & 4.30 & 1.34 & 670 & 540 & 22.84 & 6.72 & 6.45 & 2.16 & 667 & 541 \\
\hline He's temporary \& She's permanent & 25.84 & 4.96 & 4.65 & 2.47 & 1260 & 755 & 24.17 & 5.39 & 5.10 & 2.51 & 1258 & 766 \\
\hline He's temporary \& She's temporary & 26.27 & 4.59 & 4.16 & 2.46 & 243 & 156 & 24.39 & 5.22 & 4.93 & 2.50 & 244 & 159 \\
\hline He's temporary \& She's unemployed & 26.09 & 4.20 & 4.30 & 0.29 & 53 & 50 & 22.43 & 7.62 & 7.70 & 1.19 & 53 & 50 \\
\hline He's unemployed \& She's permanent & 22.58 & 6.70 & 6.42 & 2.73 & 817 & 565 & 23.50 & 5.63 & 5.41 & 2.42 & 838 & 582 \\
\hline He's unemployed \& She's temporary & 22.84 & 6.40 & 6.43 & 1.59 & 81 & 69 & 24.11 & 5.82 & 5.97 & 1.09 & 83 & 72 \\
\hline He's unemployed \& She's unemployed & 24.48 & 5.85 & 5.96 & 2.06 & 215 & 166 & 22.17 & 6.77 & 6.71 & 1.84 & 229 & 177 \\
\hline \multirow[t]{2}{*}{ Life satisfaction } & \multicolumn{4}{|c|}{ STD } & & & \multicolumn{4}{|c|}{ STD } & & \\
\hline & mean & overall & between & within & $\mathrm{N}$ & $\mathrm{n}$ & mean & overall & between & within & $\mathrm{N}$ & $\mathrm{n}$ \\
\hline He's permanent \& She's permanent & 5.33 & 1.01 & 0.89 & 0.64 & 21815 & 4677 & 5.36 & 1.08 & 0.94 & 0.69 & 21860 & 4724 \\
\hline He's permanent \& She's temporary & 5.23 & 1.05 & 1.03 & 0.42 & 1138 & 717 & 5.29 & 1.13 & 1.10 & 0.45 & 1149 & 723 \\
\hline He's permanent \& She's unemployed & 5.27 & 1.13 & 1.10 & 0.31 & 459 & 379 & 4.90 & 1.42 & 1.36 & 0.47 & 460 & 382 \\
\hline He's temporary \& She's permanent & 5.23 & 1.14 & 1.13 & 0.41 & 824 & 551 & 5.19 & 1.18 & 1.16 & 0.40 & 827 & 557 \\
\hline He's temporary \& She's temporary & 5.24 & 1.01 & 1.02 & 0.34 & 164 & 113 & 5.30 & 1.08 & 1.13 & 0.33 & 164 & 114 \\
\hline He's temporary \& She's unemployed & 5.06 & 1.06 & 1.07 & 0.13 & 33 & 32 & 4.52 & 1.60 & 1.61 & 0.00 & 33 & 32 \\
\hline He's unemployed \& She's permanent & 4.64 & 1.45 & 1.41 & 0.52 & 494 & 370 & 4.95 & 1.32 & 1.30 & 0.43 & 511 & 384 \\
\hline He's unemployed \& She's temporary & 4.79 & 1.17 & 1.19 & 0.21 & 39 & 35 & 5.05 & 1.32 & 1.30 & 0.26 & 39 & 36 \\
\hline He's unemployed \& She's unemployed & 4.92 & 1.51 & 1.45 & 0.45 & 146 & 118 & 4.59 & 1.69 & 1.59 & 0.62 & 155 & 125 \\
\hline \multirow[t]{2}{*}{ Satisfaction from partnership } & \multicolumn{4}{|c|}{ STD } & & & \multicolumn{4}{|c|}{ STD } & & \\
\hline & mean & overall & between & within & $\mathrm{N}$ & $\mathrm{n}$ & mean & overall & between & within & $\mathrm{N}$ & $\mathrm{n}$ \\
\hline He's permanent \& She's permanent & 6.35 & 1.00 & 0.87 & 0.62 & 21796 & 4666 & 6.23 & 1.12 & 0.98 & 0.69 & 21874 & 4716 \\
\hline He's permanent \& She's temporary & 6.30 & 1.02 & 0.95 & 0.39 & 1139 & 716 & 6.15 & 1.18 & 1.12 & 0.44 & 1145 & 720 \\
\hline He's permanent \& She's unemployed & 6.34 & 1.01 & 0.97 & 0.38 & 453 & 374 & 6.10 & 1.26 & 1.24 & 0.30 & 456 & 379 \\
\hline He's temporary \& She's permanent & 6.31 & 1.09 & 1.09 & 0.42 & 823 & 551 & 6.16 & 1.20 & 1.21 & 0.46 & 825 & 554 \\
\hline He's temporary \& She's temporary & 6.29 & 0.94 & 0.96 & 0.32 & 164 & 113 & 6.16 & 1.24 & 1.26 & 0.38 & 164 & 113 \\
\hline He's temporary \& She's unemployed & 6.27 & 0.94 & 0.96 & 0.00 & 33 & 32 & 5.48 & 1.79 & 1.76 & 0.00 & 33 & 32 \\
\hline He's unemployed \& She's permanent & 6.23 & 1.26 & 1.25 & 0.44 & 490 & 367 & 5.89 & 1.45 & 1.40 & 0.52 & 507 & 382 \\
\hline He's unemployed \& She's temporary & 6.08 & 1.44 & 1.49 & 0.00 & 37 & 33 & 5.92 & 1.32 & 1.35 & 0.12 & 38 & 35 \\
\hline He's unemployed \& She's unemployed & 5.96 & 1.41 & 1.42 & 0.27 & 141 & 113 & 5.91 & 1.53 & 1.40 & 0.63 & 149 & 120 \\
\hline
\end{tabular}


Table A3. Husbands' labour market insecurity and wives' subjective well-being, model comparisons

\begin{tabular}{|c|c|c|c|c|c|c|c|c|c|c|c|}
\hline & & & Psycl & ological well & being & & ife-satisfacti & & Part & ership Satisf & ction \\
\hline & Fixed-effects (xtreg, fe) & $\begin{array}{l}\text { Temporary contract } \\
\text { Unemployed }\end{array}$ & $\begin{array}{l}-0.011 * * * \\
(0.003) \\
-0.016 * * * \\
(0.004)\end{array}$ & $\begin{array}{l}-0.011 * * * \\
(0.003) \\
-0.014 * * * \\
(0.004)\end{array}$ & $\begin{array}{l}-0.011 * * * \\
(0.003) \\
-0.004 \\
(0.003)\end{array}$ & $\begin{array}{l}-0.012 * * \\
(0.005) \\
-0.016 * * * \\
(0.006)\end{array}$ & $\begin{array}{l}-0.013^{* *} \\
(0.005) \\
-0.014 * * \\
(0.006)\end{array}$ & $\begin{array}{l}-0.012 * * \\
(0.005) \\
-0.010^{*} \\
(0.006)\end{array}$ & $\begin{array}{l}-0.005 \\
(0.005) \\
-0.012 * * \\
(0.006)\end{array}$ & $\begin{array}{l}-0.005 \\
(0.005) \\
-0.012^{* *} \\
(0.006)\end{array}$ & $\begin{array}{l}-0.005 \\
(0.005) \\
-0.011 * * \\
(0.005)\end{array}$ \\
\hline 䓂 & Random-effects (xtreg, re) & $\begin{array}{l}\text { Temporary contract } \\
\text { Unemployed }\end{array}$ & $\begin{array}{l}-0.011 * * * \\
(0.003) \\
-0.023 * * * \\
(0.003) \\
\end{array}$ & $\begin{array}{l}-0.011 * * * \\
(0.003) \\
-0.019 * * * \\
(0.003) \\
\end{array}$ & $\begin{array}{l}-0.011 * * * \\
(0.003) \\
-0.009 * * * \\
(0.003) \\
\end{array}$ & $\begin{array}{l}-0.016^{* * * *} \\
(0.005) \\
-0.035 * * * \\
(0.005) \\
\end{array}$ & $\begin{array}{l}-0.016 * * * \\
(0.005) \\
-0.031 * * * \\
(0.005) \\
\end{array}$ & $\begin{array}{l}-0.014 * * * \\
(0.005) \\
-0.024 * * * \\
(0.005) \\
\end{array}$ & $\begin{array}{l}-0.009 * * \\
(0.005) \\
-0.022 * * * \\
(0.005) \\
\end{array}$ & $\begin{array}{l}-0.010 * * \\
(0.005) \\
-0.024 * * * \\
(0.005) \\
\end{array}$ & $\begin{array}{l}-0.009 * \\
(0.004) \\
-0.021 * * * \\
(0.005) \\
\end{array}$ \\
\hline & $\begin{array}{l}\text { Pooled-cross sectional linear reg. } \\
\text { (std. errors clustered by } \\
\text { individuals) }\end{array}$ & $\begin{array}{l}\text { Temporary contract } \\
\text { Unemployed }\end{array}$ & $\begin{array}{l}-0.011 * * \\
(0.005) \\
-0.030 * * * \\
(0.005)\end{array}$ & $\begin{array}{l}-0.011 * * \\
(0.005) \\
-0.022 * * * \\
(0.005)\end{array}$ & $\begin{array}{l}-0.010^{* *} \\
(0.005) \\
-0.011^{* *} \\
(0.005)\end{array}$ & $\begin{array}{l}-0.029 * * * \\
(0.008) \\
-0.060 * * * \\
(0.009)\end{array}$ & $\begin{array}{l}-0.027 * * * \\
(0.008) \\
-0.051 * * * \\
(0.009)\end{array}$ & $\begin{array}{l}-0.023 * * * \\
(0.008) \\
-0.034 * * * \\
(0.009)\end{array}$ & $\begin{array}{l}-0.019 * * * \\
(0.007) \\
-0.042 * * * \\
(0.009)\end{array}$ & $\begin{array}{l}-0.019 * * * \\
(0.007) \\
-0.043 * * * \\
(0.009)\end{array}$ & $\begin{array}{l}-0.014 * * \\
(0.007) \\
-0.035 * * * \\
(0.009)\end{array}$ \\
\hline$\tilde{\Xi}$ & Ordered logit with random effects & $\begin{array}{l}\text { Temporary contract } \\
\text { Unemployed }\end{array}$ & & & & $\begin{array}{l}-0.191 * * * \\
(0.070) \\
-0.459 * * * \\
(0.081) \\
\end{array}$ & $\begin{array}{l}-0.202 * * * \\
(0.070) \\
-0.430 * * * \\
(0.081) \\
\end{array}$ & $\begin{array}{l}-0.175 * * \\
(0.071) \\
-0.319 * * * \\
(0.082) \\
\end{array}$ & $\begin{array}{l}-0.123 \\
(0.083) \\
-0.298 * * * \\
(0.095) \\
\end{array}$ & $\begin{array}{l}-0.131 \\
(0.083) \\
-0.326^{* * *} \\
(0.095) \\
\end{array}$ & $\begin{array}{l}-0.111 \\
(0.082) \\
-0.288 * * * \\
(0.095) \\
\end{array}$ \\
\hline ర0 & Ordered logit & $\begin{array}{l}\text { Temporary contract } \\
\text { Unemployed }\end{array}$ & & & & $\begin{array}{l}-0.220 * * * \\
(0.070) \\
-0.536 * * * \\
(0.078)\end{array}$ & $\begin{array}{l}-0.216 * * * \\
(0.070) \\
-0.480 * * * \\
(0.079)\end{array}$ & $\begin{array}{l}-0.183 * * * \\
(0.069) \\
-0.315 * * * \\
(0.081)\end{array}$ & $\begin{array}{l}-0.161 * * \\
(0.072) \\
-0.296 * * * \\
(0.086)\end{array}$ & $\begin{array}{l}-0.156^{* *} \\
(0.072) \\
-0.326^{* * *} \\
(0.086)\end{array}$ & $\begin{array}{l}-0.122^{*} \\
(0.071) \\
-0.272 * * * \\
(0.086)\end{array}$ \\
\hline $\begin{array}{l}\overparen{*} \\
\stackrel{0}{\frac{\theta}{0}}\end{array}$ & Fixed-effects (xtlogit, fe) & $\begin{array}{l}\text { Temporary contract } \\
\text { Unemployed }\end{array}$ & $\begin{array}{l}-0.184 \\
(0.165) \\
0.108 \\
(0.146) \\
\end{array}$ & $\begin{array}{l}-0.162 \\
(0.165) \\
0.073 \\
(0.148) \\
\end{array}$ & $\begin{array}{l}-0.156 \\
(0.169) \\
-0.114 \\
(0.150) \\
\end{array}$ & $\begin{array}{l}0.280 * \\
(0.145) \\
0.290 * * \\
(0.143) \\
\end{array}$ & $\begin{array}{l}0.273^{*} \\
(0.146) \\
0.216 \\
(0.145) \\
\end{array}$ & $\begin{array}{l}0.249^{*} \\
(0.147) \\
0.111 \\
(0.147) \\
\end{array}$ & $\begin{array}{l}0.143 \\
(0.199) \\
0.158 \\
(0.200) \\
\end{array}$ & $\begin{array}{l}0.165 \\
(0.199) \\
0.179 \\
(0.200) \\
\end{array}$ & $\begin{array}{l}0.129 \\
(0.207) \\
0.199 \\
(0.208) \\
\end{array}$ \\
\hline $\begin{array}{l}0 \\
0 \\
0 \\
0 \\
0 \\
0 \\
0 \\
0\end{array}$ & Random-effects (xtlogit, re) & $\begin{array}{l}\text { Temporary contract } \\
\text { Unemployed }\end{array}$ & $\begin{array}{l}-0.094 \\
(0.150) \\
0.366 * * * \\
(0.124) \\
\end{array}$ & $\begin{array}{l}-0.108 \\
(0.150) \\
0.210^{*} \\
(0.125) \\
\end{array}$ & $\begin{array}{l}-0.130 \\
(0.152) \\
-0.018 \\
(0.127) \\
\end{array}$ & $\begin{array}{l}0.433 * * * \\
(0.132) \\
0.720 * * * \\
(0.124) \\
\end{array}$ & $\begin{array}{l}0.389 * * * \\
(0.133) \\
0.540 * * * \\
(0.126) \\
\end{array}$ & $\begin{array}{l}0.331 * * \\
(0.133) \\
0.355^{* * *} \\
(0.126) \\
\end{array}$ & $\begin{array}{l}0.354 * * \\
(0.176) \\
0.580 * * * \\
(0.169) \\
\end{array}$ & $\begin{array}{l}0.359 * * \\
(0.176) \\
0.586 * * * \\
(0.171) \\
\end{array}$ & $\begin{array}{l}0.318^{*} \\
(0.179) \\
0.525^{* * *} \\
(0.173) \\
\end{array}$ \\
\hline 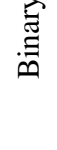 & $\begin{array}{l}\text { Pooled-cross sectional non-linear } \\
\text { reg. (std. errors clustered by } \\
\text { individuals) }\end{array}$ & $\begin{array}{l}\text { Temporary contract } \\
\text { Unemployed }\end{array}$ & $\begin{array}{l}0.010 \\
(0.155) \\
0.346^{* * *} \\
(0.108)\end{array}$ & $\begin{array}{l}-0.026 \\
(0.156) \\
0.119 \\
(0.110)\end{array}$ & $\begin{array}{l}-0.055 \\
(0.158) \\
-0.057 \\
(0.111)\end{array}$ & $\begin{array}{l}0.438 * * * \\
(0.124) \\
0.655^{* * *} \\
(0.106)\end{array}$ & $\begin{array}{l}0.381 * * * \\
(0.125) \\
0.436 * * * \\
(0.109)\end{array}$ & $\begin{array}{l}0.324 * * * \\
(0.125) \\
0.250 * * \\
(0.112)\end{array}$ & $\begin{array}{l}0.379 * * * \\
(0.144) \\
0.621 * * * \\
(0.143)\end{array}$ & $\begin{array}{l}0.366^{* *} \\
(0.144) \\
0.606 * * * \\
(0.143)\end{array}$ & $\begin{array}{l}0.316^{* *} \\
(0.148) \\
0.504 * * * \\
(0.150)\end{array}$ \\
\hline
\end{tabular}

Notes: Permanent employee is the reference category. Individual controls: Financial difficulty, Local Unemployment Rate, Partner's corresponding well-being indicator, Years spent in relationship, Presence of children, Age, Age-squared, Cohabitation dummy, and year dummy. Standard errors in parenthesis. Hausman test suggests that all of the random effect estimations produced biased coefficients. ${ }^{*} \mathrm{GHQ}$ is coded as one if the values are below 12 , and satisfaction indicators are coded as one if values are equal to or are below 3 . 
Table A4. Wives' labour market insecurity and husband's subjective well-being, model comparisons

\begin{tabular}{|c|c|c|c|c|c|c|c|c|c|c|c|}
\hline \multirow{4}{*}{ 泀 } & \multirow[b]{2}{*}{$\begin{array}{l}\text { Fixed-effects } \\
\text { (xtreg, fe) }\end{array}$} & \multirow[b]{2}{*}{$\begin{array}{l}\text { Temporary contract } \\
\text { Unemployed }\end{array}$} & \multicolumn{3}{|c|}{ Psychological well-being } & \multicolumn{3}{|c|}{ Life-satisfaction } & \multicolumn{3}{|c|}{ Partnership Satisfaction } \\
\hline & & & $\begin{array}{l}-0.004 \\
(0.003) \\
-0.003 \\
(0.004) \\
\end{array}$ & $\begin{array}{l}-0.004 \\
(0.003) \\
-0.001 \\
(0.004) \\
\end{array}$ & $\begin{array}{l}-0.005^{*} \\
(0.003) \\
0.004 \\
(0.004) \\
\end{array}$ & $\begin{array}{l}0.002 \\
(0.005) \\
-0.001 \\
(0.006) \\
\end{array}$ & $\begin{array}{l}0.002 \\
(0.005) \\
0.003 \\
(0.006)\end{array}$ & $\begin{array}{l}-0.000 \\
(0.005) \\
0.005 \\
(0.006) \\
\end{array}$ & $\begin{array}{l}0.005 \\
(0.004) \\
0.012 * * \\
(0.006) \\
\end{array}$ & $\begin{array}{l}0.005 \\
(0.004) \\
0.013 * * \\
(0.006) \\
\end{array}$ & $\begin{array}{l}0.003 \\
(0.004) \\
0.012 * * \\
(0.006) \\
\end{array}$ \\
\hline & $\begin{array}{l}\text { Random-effects } \\
\text { (xtreg, re) }\end{array}$ & $\begin{array}{l}\text { Temporary contract } \\
\text { Unemployed }\end{array}$ & $\begin{array}{l}-0.005^{*} \\
(0.003) \\
-0.005 \\
(0.004) \\
\end{array}$ & $\begin{array}{l}-0.004 \\
(0.003) \\
0.000 \\
(0.004)\end{array}$ & $\begin{array}{l}-0.005^{*} \\
(0.003) \\
0.006 \\
(0.004) \\
\end{array}$ & $\begin{array}{l}-0.000 \\
(0.004) \\
-0.009 \\
(0.006)\end{array}$ & $\begin{array}{l}0.000 \\
(0.004) \\
-0.003 \\
(0.006)\end{array}$ & $\begin{array}{l}-0.001 \\
(0.004) \\
0.002 \\
(0.006)\end{array}$ & $\begin{array}{l}0.002 \\
(0.004) \\
0.004 \\
(0.006) \\
\end{array}$ & $\begin{array}{l}0.003 \\
(0.004) \\
0.005 \\
(0.006) \\
\end{array}$ & $\begin{array}{l}0.001 \\
(0.004) \\
0.006 \\
(0.006)\end{array}$ \\
\hline & $\begin{array}{l}\text { Pooled-cross sectional } \\
\text { linear regression (std. } \\
\text { errors clustered by } \\
\text { individuals) }\end{array}$ & $\begin{array}{l}\text { Temporary contract } \\
\text { Unemployed }\end{array}$ & $\begin{array}{l}-0.008 * * \\
(0.004) \\
-0.003 \\
(0.005) \\
\end{array}$ & $\begin{array}{l}-0.006 \\
(0.004) \\
0.006 \\
(0.005) \\
\end{array}$ & $\begin{array}{l}-0.007 * \\
(0.004) \\
0.013 * * * \\
(0.005) \\
\end{array}$ & $\begin{array}{l}-0.006 \\
(0.006) \\
-0.023 * * \\
(0.010) \\
\end{array}$ & $\begin{array}{l}-0.004 \\
(0.006) \\
-0.009 \\
(0.009) \\
\end{array}$ & $\begin{array}{l}-0.004 \\
(0.006) \\
0.004 \\
(0.009) \\
\end{array}$ & $\begin{array}{l}-0.008 \\
(0.006) \\
-0.013 \\
(0.008) \\
\end{array}$ & $\begin{array}{l}-0.007 \\
(0.006) \\
-0.010 \\
(0.008) \\
\end{array}$ & $\begin{array}{l}-0.004 \\
(0.006) \\
-0.004 \\
(0.008) \\
\end{array}$ \\
\hline \multirow{2}{*}{ 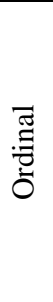 } & $\begin{array}{l}\text { Ordered logit with } \\
\text { random effects }\end{array}$ & $\begin{array}{l}\text { Temporary contract } \\
\text { Unemployed }\end{array}$ & & & & $\begin{array}{l}-0.077 \\
(0.096) \\
-0.004 \\
(0.063) \\
\end{array}$ & $\begin{array}{l}-0.004 \\
(0.095) \\
0.003 \\
(0.064) \\
\end{array}$ & $\begin{array}{l}0.063 \\
(0.094) \\
-0.022 \\
(0.063) \\
\end{array}$ & $\begin{array}{l}0.147 \\
(0.122) \\
0.045 \\
(0.077) \\
\end{array}$ & $\begin{array}{l}0.158 \\
(0.122) \\
0.049 \\
(0.077) \\
\end{array}$ & $\begin{array}{l}0.153 \\
(0.119) \\
0.039 \\
(0.078) \\
\end{array}$ \\
\hline & Ordered logit & $\begin{array}{l}\text { Temporary contract } \\
\text { Unemployed }\end{array}$ & & & & $\begin{array}{l}-0.083 \\
(0.060) \\
-0.202 * * \\
(0.095)\end{array}$ & $\begin{array}{l}-0.063 \\
(0.061) \\
-0.095 \\
(0.092)\end{array}$ & $\begin{array}{l}-0.058 \\
(0.060) \\
0.044 \\
(0.092)\end{array}$ & $\begin{array}{l}-0.142 * * \\
(0.071) \\
-0.094 \\
(0.094)\end{array}$ & $\begin{array}{l}-0.138^{*} \\
(0.071) \\
-0.091 \\
(0.093)\end{array}$ & $\begin{array}{l}-0.113 \\
(0.073) \\
-0.031 \\
(0.096)\end{array}$ \\
\hline \multirow{3}{*}{ 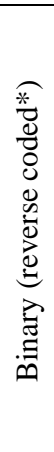 } & $\begin{array}{l}\text { Fixed-effects } \\
\text { (xtlogit, fe) }\end{array}$ & $\begin{array}{l}\text { Temporary contract } \\
\text { Unemployed }\end{array}$ & $\begin{array}{l}0.250 \\
(0.193) \\
0.196 \\
(0.254) \\
\end{array}$ & $\begin{array}{l}0.254 \\
(0.197) \\
0.038 \\
(0.262) \\
\end{array}$ & $\begin{array}{l}0.299 \\
(0.201) \\
-0.142 \\
(0.270) \\
\end{array}$ & $\begin{array}{l}-0.006 \\
(0.154) \\
0.260 \\
(0.188) \\
\end{array}$ & $\begin{array}{l}0.022 \\
(0.156) \\
0.140 \\
(0.193) \\
\end{array}$ & $\begin{array}{l}0.033 \\
(0.158) \\
0.118 \\
(0.195) \\
\end{array}$ & $\begin{array}{l}0.102 \\
(0.245) \\
0.108 \\
(0.288) \\
\end{array}$ & $\begin{array}{l}0.095 \\
(0.246) \\
0.080 \\
(0.289) \\
\end{array}$ & $\begin{array}{l}0.075 \\
(0.257) \\
0.069 \\
(0.304) \\
\end{array}$ \\
\hline & $\begin{array}{l}\text { Random-effects (xtlogit, } \\
\text { re) }\end{array}$ & $\begin{array}{l}\text { Temporary contract } \\
\text { Unemployed }\end{array}$ & $\begin{array}{l}0.339^{*} \\
(0.175) \\
0.365 \\
(0.226) \\
\end{array}$ & $\begin{array}{l}0.290^{*} \\
(0.176) \\
0.009 \\
(0.230) \\
\end{array}$ & $\begin{array}{l}0.328^{*} \\
(0.178) \\
-0.212 \\
(0.234) \\
\end{array}$ & $\begin{array}{l}0.022 \\
(0.145) \\
0.585 * * * \\
(0.169) \\
\end{array}$ & $\begin{array}{l}0.013 \\
(0.145) \\
0.293 * \\
(0.173) \\
\end{array}$ & $\begin{array}{l}0.016 \\
(0.145) \\
0.180 \\
(0.173) \\
\end{array}$ & $\begin{array}{l}0.079 \\
(0.225) \\
0.355 \\
(0.266) \\
\end{array}$ & $\begin{array}{l}0.054 \\
(0.225) \\
0.250 \\
(0.268) \\
\end{array}$ & $\begin{array}{l}0.004 \\
(0.231) \\
0.211 \\
(0.274) \\
\end{array}$ \\
\hline & $\begin{array}{l}\text { Pooled-cross sectional } \\
\text { non-linear regression } \\
\text { (std. errors clustered by } \\
\text { individuals) }\end{array}$ & $\begin{array}{l}\text { Temporary contract } \\
\text { Unemployed }\end{array}$ & $\begin{array}{l}0.225 \\
(0.157) \\
0.298 \\
(0.200)\end{array}$ & $\begin{array}{l}0.178 \\
(0.164) \\
-0.086 \\
(0.206)\end{array}$ & $\begin{array}{l}0.222 \\
(0.163) \\
-0.260 \\
(0.213)\end{array}$ & $\begin{array}{l}0.061 \\
(0.122) \\
0.531 * * * \\
(0.135)\end{array}$ & $\begin{array}{l}0.033 \\
(0.127) \\
0.225 \\
(0.141)\end{array}$ & $\begin{array}{l}0.033 \\
(0.127) \\
0.051 \\
(0.143)\end{array}$ & $\begin{array}{l}0.009 \\
(0.209) \\
0.381^{*} \\
(0.214)\end{array}$ & $\begin{array}{l}-0.008 \\
(0.211) \\
0.249 \\
(0.212)\end{array}$ & $\begin{array}{l}-0.064 \\
(0.214) \\
0.133 \\
(0.222)\end{array}$ \\
\hline
\end{tabular}

Notes: Permanent employee is the reference category. Individual controls: Financial difficulty, Local Unemployment Rate, Partner's corresponding well-being indicator, Years spent in relationship, Presence of children, Age, Age-squared, Cohabitation dummy, and year dummy. Standard errors in parenthesis. Hausman test suggests that all of the random effect estimations produced biased coefficients. ${ }^{*} \mathrm{GHQ}$ is coded as one if the values are below 12 , and satisfaction indicators are coded as one if values are equal to or are below 3 . 